\title{
Microbial and metabolomic mechanisms mediating the effects of dietary inulin and cellulose supplementation on porcine oocyte and uterine development
}

Zhaoyue Men ${ }^{1,2+}$, Meng Cao ${ }^{1+}$, Yuechan Gong ${ }^{1 \dagger}$, Lun Hua ${ }^{1}$, Ruihao Zhang ${ }^{1,2}$, Xin Zhu ${ }^{1,2}$, Lianchao Tang ${ }^{1}$, Xuemei Jiang ${ }^{1}$, Shengyu $\mathrm{Xu}^{1}$, Jian $\mathrm{Li}^{1}$, Lianqiang Che ${ }^{1}$, Yan Lin ${ }^{1}$, Bin Feng ${ }^{1}$, Zhengfeng Fang ${ }^{1}$, De $\mathrm{Wu}^{1}$ and Yong Zhuo ${ }^{1 *}$ (i)

\begin{abstract}
Background: Dietary fiber (DF) is often eschewed in swine diet due to its anti-nutritional effects, but DF is attracting growing attention for its reproductive benefits. The objective of this study was to investigate the effects of DF intake level on oocyte maturation and uterine development, to determine the optimal DF intake for gilts, and gain microbial and metabolomic insight into the underlying mechanisms involved.

Methods: Seventy-six Landrace $\times$ Yorkshire $(L Y)$ crossbred replacement gilts of similar age $(92.6 \pm 0.6 \mathrm{~d}$; mean \pm standard deviation [SD]) and body weight (BW, $33.8 \pm 3.9 \mathrm{~kg}$; mean $\pm \mathrm{SD}$ ) were randomly allocated to 4 dietary treatment groups ( $n=19)$; a basal diet without extra DF intake (DF 1.0), and 3 dietary groups ingesting an extra 50\% (DF 1.5), 75\% (DF 1.75), and 100\% (DF 2.0) dietary fiber mixture consisting of inulin and cellulose (1:4). Oocyte maturation and uterine development were assessed on $19 \mathrm{~d}$ of the 2 nd oestrous cycle. Microbial diversity of faecal samples was analysed by high-throughput pyrosequencing (16S rRNA) and blood samples were subjected to untargeted metabolomics.
\end{abstract}

Results: The rates of oocytes showing first polar bodies after in vitro maturation for $44 \mathrm{~h}$ and uterine development increased linearly with increasing DF intake; DF 1.75 gilts had a $19.8 \%$ faster oocyte maturation rate and a $48.9 \mathrm{~cm}$ longer uterus than DF 1.0 gilts $(P<0.05)$. Among the top 10 microbiota components at the phylum level, 8 increased linearly with increasing DF level, and the relative abundance of 30 of 53 microbiota components at the genus level (>0.1\%) increased linearly or quadratically with increasing DF intake. Untargeted metabolic analysis revealed significant changes in serum metabolites that were closely associated with microbiota, including serotonin, a gut-derived signal that stimulates oocyte maturation.

\footnotetext{
* Correspondence: zhuoyong@sicau.edu.cn

'Zhaoyue Men, Meng Cao and Yuechan Gong contributed equally to this work.

${ }^{1}$ Animal Nutrition Institute, Sichuan Agricultural University, 211 Huimin Road, Wenjiang District, Chengdu 611130, People's Republic of China

Full list of author information is available at the end of the article
}

C The Author(s). 2022 Open Access This article is licensed under a Creative Commons Attribution 4.0 International License, which permits use, sharing, adaptation, distribution and reproduction in any medium or format, as long as you give appropriate credit to the original author(s) and the source, provide a link to the Creative Commons licence, and indicate if changes were made. The images or other third party material in this article are included in the article's Creative Commons licence, unless indicated otherwise in a credit line to the material. If material is not included in the article's Creative Commons licence and your intended use is not permitted by statutory regulation or exceeds the permitted use, you will need to obtain permission directly from the copyright holder. To view a copy of this licence, visit http://creativecommons.org/licenses/by/4.0/. The Creative Commons Public Domain Dedication waiver (http://creativecommons.org/publicdomain/zero/1.0/) applies to the data made available in this article, unless otherwise stated in a credit line to the data. 
Conclusions: The findings provide evidence of the benefits of increased DF intake by supplementing inulin and cellulose on oocyte maturation and uterine development in gilts, and new microbial and metabolomic insight into the mechanisms mediating the effects of DF on reproductive performance of replacement gilts.

Keywords: Dietary fiber, Gilts, Metabolomics, Microbiota, Oocyte maturation

\section{Background}

Dietary fiber (DF) is often excluded from animal feed due to its anti-nutritional properties during nutrient digestion in monogastric nutrition $[1,2]$. However, DF reportedly benefits swine production, including improving the welfare of gestating sows fed a restricted diet [3]. In recent decades, the inclusion of DF in the diets of replacement gilts has received growing attention due to its beneficial effects on reproductive performance. Gilts fed a fiber-rich diet by adding high levels of sugar beet pulp $19 \mathrm{~d}$ prior to breeding displayed greater embryo survival $(88.2 \%)$ at $28 \mathrm{~d}$ of pregnancy than controls $(80.0 \%)$, while increasing the feeding level (from $1.8 \times$ maintenance to $2.6 \times$ maintenance $)$, starch $(+451 \mathrm{~g} / \mathrm{d})$ or protein $(+158$ g/d) did not improve embryonic survival [4]. Furthermore, this beneficial effect of high DF prior to mating on the survival of early embryos acted by improving the quality of oocytes [5]. However, feeding replacement gilts a lupin-based high-fiber diet, but not a wheat branbased diet, accelerated oocyte maturation [6], adding complexity to the effects of DF on the reproductive outcomes of gilts. Most previous researches on the effects of fiber have explored high levels of fiber-rich ingredients such as sugar beet pulp. However, other nutrients (e.g., vitamins) complicate the direct effects of DF. Adding extracted forms of fiber such as inulin, cellulose and pectin allows the direct evaluation of the effect of DF [7-10]. Recently, we investigated the effects of different levels of DF intake on the ovarian follicle reserve of gilts [7], but the optimal level of dietary fiber for oocyte maturation and uterine development in gilts of mating age remains unknown.

As mentioned above, some of the beneficial effects of DF on reproductive performance have been elucidated, but the underlying mechanism remains largely uncertain. DF is usually mobilised by gut microbiota to generate short-chain fatty acids (SCFAs) such as acetate, propionate and butyrate [11]. Additionally, SCFAs can be taken up by peripheral tissues such as the stomach, intestine, liver, adipocytes and skeletal muscle, making it difficult for them to reach threshold concentrations to activate downstream targets $[11,12]$. Peripheral tissues in turn detect metabolites and respond accordingly by secreting secondary metabolic hormones such as serotonin [13]. However, it remains unclear which metabolites or metabolic hormones are involved in controlling the reproductive functions of replacement gilts.
Indeed, DF is generally defined as a carbohydrate that is neither absorbed nor hydrolysable by mammalian endogenous digestive enzymes. Although DF is gradually considered as an essential nutrient for normal gastrointestinal tract physiology and overall health of both human and domestic animals, there have been different methods for the quantification of DF within feeds/foods for both animal and human nutrition [14, 15]. "Crude fiber" (CF) was one of the earliest parameters to describe the DF, and later the Van Soest method was introduced to classify the DF into neutral detergent fiber (NDF), acid detergent fiber (ADF), and acid detergent lignin (ADF) in animal nutrition [15]. More recently, a simple classification of DF was introduced with enzymaticgravimetric method, which allows the categorization of DF into "soluble" or "insoluble" based on the ability to be fully dispersed with water [16]. Soluble fiber has generally a high affinity in the water, and is easily hydrolyzed by the carbohydrate-active enzymes secreted by the microbiota in the gut, whereas insoluble fiber was less fermentable [1]. Additionally, the DF benefits could be attributed to its different physical characteristics such as water-holding capacity, viscosity, absorptive capacity, and faecal bulking capacity, as well as chemical characteristic fermentability [17]. Insoluble fibers (e.g. cellulose) usually related to water-holding capacity, absorptive capacity, and faecal bulking capacity, while soluble fibers (e.g. inulin) usually contributed to viscosity and fermentability [1]. This leads us to hypothesize that a combination of both soluble and insoluble fiber could optimize the effects of DF. The objective of this study was to investigate the effects of different DF levels by supplementing inulin and cellulose to the diets of growing gilts on oocyte quality and uterine development. We also probed changes in microbial diversity, performed metabolomic profiling based on 16S rRNA analysis, and conducted untargeted metabolic pathway analysis.

\section{Materials and methods}

This trial was conducted at the research centre of $\mathrm{Si}$ chuan Agricultural University. Procedures were performed in accordance with the National Research Council Guide for the Care and Use of Laboratory Animals, and followed the regulations of the Animal Care and Use Committee of Sichuan Agricultural University (Approval No. 20174310). 


\section{Animals, diets and experimental design}

This was a companion trial of our recent study [7]. Seventy-six Landrace $\times$ Yorkshire (LY) crossbred replacement gilts of similar age $(92.6 \pm 0.6 \mathrm{~d}$; mean $\pm \mathrm{SD})$ and body weight $(33.8 \pm 3.9 \mathrm{~kg}$; mean $\pm \mathrm{SD})$ were used in this study. Gilts were randomly allocated to 4 dietary treatment groups $(n=19)$; a basal diet without extra DF intake (DF 1.0), and 3 dietary groups with 3 different levels of extra DF intake. Basal diets were divided into 2 phases; 1 to $60 \mathrm{~d}$ (72.0\% corn, $20.8 \%$ soybean) and $61 \mathrm{~d}$ to the end of the experiment $(78.0 \%$ corn, $16.0 \%$ soybean), respectively. The detailed diet formulation was shown in Table 1 . The diet from 1 to $60 \mathrm{~d}$ of experiment

Table 1 Ingredients and nutrient compositions of basal diets (as fed basis), g/kg

\begin{tabular}{|c|c|c|}
\hline \multirow[t]{2}{*}{ Ingredients, g/kg } & \multicolumn{2}{|c|}{ Phases of experiment } \\
\hline & $1-60 d$ & $61 \mathrm{~d}$-slaughter ${ }^{3}$ \\
\hline Corn & 720 & 780 \\
\hline Soybean (44\%CP) & 208 & 160 \\
\hline Fish meal $(65 \% \mathrm{CP})$ & 25 & 20 \\
\hline Soybean oil & 20 & 17 \\
\hline L-Lys HCl (98\%) & 3 & 2 \\
\hline DL-Met (99\%) & 1 & 0.4 \\
\hline L-Thr (98\%) & 0.6 & 0.2 \\
\hline L-Trp (98\%) & 0.1 & 0 \\
\hline Choline chloride (50\%) & 1.5 & 1.5 \\
\hline Sodium chloride (feed grade, > 99.0\%) & 4 & 4 \\
\hline Limestone & 6.2 & 5.9 \\
\hline Monocalcium phosphate & 8.6 & 7 \\
\hline Vitamin-mineral premix $^{1}$ & 2 & 2 \\
\hline Total & 1000 & 1000 \\
\hline \multicolumn{3}{|l|}{ Nutrient composition, $\mathrm{g} / \mathrm{kg}$} \\
\hline Digestible energy, Mcal/kg & 3.4 & 3.4 \\
\hline Crude protein & 169.1 & 147.2 \\
\hline Total Lysine & 10.8 & 8.6 \\
\hline SID Lysine & 9.8 & 7.8 \\
\hline Calcium & 6.9 & 5.9 \\
\hline Total phosphorus & 5.9 & 5.3 \\
\hline Soluble fiber & 10.2 & 10.3 \\
\hline Insoluble fiber & 115.0 & 113.9 \\
\hline Total dietary fiber ${ }^{2}$ & 125.2 & 124.2 \\
\hline
\end{tabular}

${ }^{1}$ Provided the following per kilogram of basal diet: $8000 \mathrm{IU}$ vitamin A; $800 \mathrm{IU}$ vitamin $D_{3} ; 30 \mathrm{IU}$ vitamin $\mathrm{E}_{;} 4 \mathrm{mg}$ vitamin $\mathrm{K} ; 0.16 \mathrm{mg}$ biotin; $2 \mathrm{mg}$ folacin; 25 $\mathrm{mg}$ niacin; $20 \mathrm{mg}$ pantothenic acid; $10 \mathrm{mg}$ riboflavin; $2 \mathrm{mg}$ thiamine; $1 \mathrm{mg}$ vitamin $B_{6} ; 20 \mu g$ vitamin $B_{12} ; 16 \mathrm{mg}$ copper as as copper sulfate; $0.25 \mathrm{mg}$ iodine as potassium iodide; $125 \mathrm{mg}$ iron as ferrous sulphate; $30 \mathrm{mg}$ manganese as manganese sulfate; $0.25 \mathrm{mg}$ selenium as sodium selenite; 125 $\mathrm{mg}$ zinc as zinc sulfate

${ }^{2}$ Total dietary fiber $=$ soluble fiber + insoluble fiber, analyzed value according to method AOAC 991.43

${ }^{3}$ Gilts were slaughtered at the 19th day of 3rd estrous cycle contained $72.0 \%$ corn, $20.8 \%$ soybean meal, $2.5 \%$ fishmeal, and $2.0 \%$ soybean meal to provide $3.4 \mathrm{Mcal} / \mathrm{kg}$ of digestible energy, $16.9 \%$ of crude protein, and $1.08 \%$ of total lysine. The diet from $61 \mathrm{~d}$ to the end of experiment contained $78.0 \%$ corn, $16.0 \%$ soybean meal, $2.0 \%$ fishmeal, and $1.7 \%$ soybean meal to provide $3.4 \mathrm{Mcal} / \mathrm{kg}$ of digestible energy, $14.7 \%$ of crude protein, and $0.86 \%$ of total lysine. The soluble and insoluble fibers in basal diets were analysed by enzymatic-gravimetric method with minor modification [10]. Briefly, feed samples (1.0 g) were treated with a 40-mL MES-TRIS buffer solution (Sigma-Aldrich, Saint Louis, USA) on a stirrer. The heat-stable $\alpha$-amylase solution $(50 \mu \mathrm{L}, \mathrm{A} 3306$, SigmaAldrich) was added to the mixture and then incubated in a $95-100^{\circ} \mathrm{C}$ water bath for $15 \mathrm{~min}$ with continuous agitation. The protease solution (P3910, Sigma-Aldrich) were then added for $30 \mathrm{~min}$ at $60^{\circ} \mathrm{C}$. Additional $300 \mu \mathrm{L}$ amyloglucosidase solution (A9913, Sigma-Aldrich) was added to the solution for $30 \mathrm{~min}$ at $60^{\circ} \mathrm{C}$ after adjusting $\mathrm{pH}$ to 4.0-4.7. After hydrolysis, the insoluble fiber residue was obtained by filtration on a crucible with acid washed wet and redistribute Celite (C8656, SigmaAldrich), and the filtrate was collected by adding $95 \%$ ethanol prewarmed at $60^{\circ} \mathrm{C}$ to form the SDF precipitate. Total DF were calculated with sum of soluble fiber and insoluble fiber. The total DF in basal diets were $12.52 \%$ (d 1 to 60 of experiment) and 12.42\% (d 61 to the end of experiment), respectively. DF 1.0 gilts were provided with 1.6, 2.1, 2.5 and $2.8 \mathrm{~kg} / \mathrm{d}$ of basal diet and estimated total DF intake from diets was 200.3, 262.9, 310.5 and $347.8 \mathrm{~g} / \mathrm{d}$ from 1 to $30 \mathrm{~d}, 31$ to $60 \mathrm{~d}, 61$ to $120 \mathrm{~d}$, and $121 \mathrm{~d}$ to the end of the experiment, respectively. During each feeding phase, gilts were fed a basal diet supplemented with 50\% (DF 1.5), 75\% (DF 1.75) and 100\% (DF 2.0) extra DF compared with gilts in the DF 1.0 group (Fig. 1). Equal amounts of feed were provided to gilts twice daily at 08:00 and 14:30 h. Extracted DF inulin and cellulose were composed of a 1:4 ratio, and this ratio was formulated as previously described [7, 8, 10]. All gilts were individually housed in a pen $(2.0 \mathrm{~m} \times 0.8 \mathrm{~m})$ in

\begin{tabular}{|c|c|c|c|c|c|c|c|c|}
\hline & \multicolumn{2}{|c|}{ d 1 to 30} & \multicolumn{2}{|c|}{ d 31 to 60} & \multicolumn{2}{|c|}{ d 61 to 120} & \multicolumn{2}{|c|}{ d 121 to end } \\
\hline DF 1.0 & \begin{tabular}{|c|} 
Basal diet 1 \\
$1.6 \mathrm{~kg} / \mathrm{d}$
\end{tabular} & & \begin{tabular}{|c|} 
Basal diet 1 \\
$1.8 \mathrm{~kg} / \mathrm{d}$
\end{tabular} & & \begin{tabular}{|c|} 
Basal diet 2 \\
$2.1 \mathrm{~kg} / \mathrm{d}$
\end{tabular} & & $\begin{array}{c}\text { Basal diet } 2 \\
2.8 \mathrm{~kg} / \mathrm{d}\end{array}$ & \\
\hline DF 1.5 & \begin{tabular}{|c|} 
Basal diet 1 \\
$1.6 \mathrm{~kg} / \mathrm{d}$
\end{tabular} & $\begin{array}{l}\text { (1F) } \\
100 \mathrm{~g} / \mathrm{d}\end{array}$ & \begin{tabular}{|c|} 
Basal diet 1 \\
$1.8 \mathrm{~kg} / \mathrm{d}$ \\
\end{tabular} & $\begin{array}{l}\text { DFP } \\
132 \mathrm{~g} / \mathrm{d}\end{array}$ & \begin{tabular}{|c|} 
Basal diet 2 \\
$2.1 \mathrm{~kg} / \mathrm{d}$
\end{tabular} & $\frac{D F}{155 \mathrm{~g} / \mathrm{d}}$ & $\begin{array}{l}\text { Basal dict } 2 \\
2.8 \mathrm{~kg} / \mathrm{d}\end{array}$ & $\begin{array}{l}\text { DF) } \\
174 \mathrm{~g} / \mathrm{d}\end{array}$ \\
\hline DF 1.75 & \begin{tabular}{|c|} 
Basal diet 1 \\
$1.6 \mathrm{~kg} / \mathrm{d}$
\end{tabular} & $\begin{array}{l}\text { एFPEF } \\
150 \mathrm{~g} / \mathrm{d}\end{array}$ & \begin{tabular}{|c|} 
Basal diet 1 \\
$1.8 \mathrm{~kg} / \mathrm{d}$
\end{tabular} & $\begin{array}{l}\text { DPDPF } \\
197 \mathrm{~g} / \mathrm{d}\end{array}$ & \begin{tabular}{|c|} 
Basal diet 2 \\
$2.1 \mathrm{~kg} / \mathrm{d}$
\end{tabular} & $\begin{array}{l}\text { DFPF } \\
232 \mathrm{~g} / \mathrm{d}\end{array}$ & $\begin{array}{l}\text { Basal dict } 2 \\
2.8 \mathrm{~kg} / \mathrm{d}\end{array}$ & $\begin{array}{l}\text { DPDPF) } \\
260 \mathrm{~g} / \mathrm{d}\end{array}$ \\
\hline DF 2.0 & \begin{tabular}{|c|} 
Basal diet I \\
$1.6 \mathrm{~kg} / \mathrm{d}$
\end{tabular} & $\begin{array}{l}\text { DADPDPF } \\
200 \mathrm{~g} / \mathrm{d}\end{array}$ & \begin{tabular}{|c|} 
Basal diet 1 \\
$1.8 \mathrm{~kg} / \mathrm{d}$
\end{tabular} & $\begin{array}{l}\text { DPDPDDP } \\
262 \mathrm{~g} / \mathrm{d}\end{array}$ & \begin{tabular}{|c|} 
Basal diet 2 \\
$2.1 \mathrm{~kg} / \mathrm{d}$
\end{tabular} & $\begin{array}{l}\text { DPDPDDP } \\
310 \mathrm{~g} / \mathrm{d}\end{array}$ & $\begin{array}{c}\text { Basal diet } 2 \\
2.8 \mathrm{~kg} / \mathrm{d}\end{array}$ & $\begin{array}{l}\text { DPDPP(DF) } \\
374 \mathrm{~g} / \mathrm{d}\end{array}$ \\
\hline
\end{tabular}

Fig. 1 Schematic diagram of the experimental design. Two basal diets were formulated during 1 to $60 \mathrm{~d}$ and $61 \mathrm{~d}$ to the end of the experiment. Gilts were fed a basal diet, or a basal diet with three levels of extra dietary fiber (DF) during each phase. DF 1.0, basal diet without DF supplement, and DF 1.5, DF 1.75, and DF 2.0 were basal diets with an additional 50\%,75\% and 100\% DF, respectively. The DF mixture comprised inulin and cellulose at a ratio of 1:4 
a breeding facility with an environmental temperature maintained between $20^{\circ} \mathrm{C}$ and $24^{\circ} \mathrm{C}$. Water was provided ad libitum. The onset of first puberty and the 2 nd oestrous cycle were carefully checked in order to collect ovarian samples on $19 \mathrm{~d}$ of the 2 nd oestrous cycle [7].

\section{Sample collection}

Blood samples were collected from gilts at $2 \mathrm{~h}$ after the morning meal at both $30 \mathrm{~d}$ of the experiment and $19 \mathrm{~d}$ of the 2nd oestrous cycle. Blood samples were centrifuged at $3000 \times g$ at $4{ }^{\circ} \mathrm{C}$ for $30 \mathrm{~min}$ to collect serum, and stored at $-20^{\circ} \mathrm{C}$ for future analysis.

Faecal samples were randomly collected $(n=8$ per group) at $30 \mathrm{~d}$ of the experiment and at $19 \mathrm{~d}$ of the 2 nd oestrous cycle. Defecation was promoted by rectal stimulation and faeces were collected immediately, transferred into sterile tubes with a sterile cotton swab pre-wetted with ice-cold sterile phosphate-buffered saline (PBS, $\mathrm{pH} 7.2$ ), immediately snap-frozen in liquid $\mathrm{N}_{2}$, and stored at $-80^{\circ} \mathrm{C}$. All contacts with faeces were kept sterile during the entire sampling procedure to avoid contamination.

Collection of reproductive organs was performed at 2 time points. At $30 \mathrm{~d}$ of the experiment, 24 gilts $(6$ gilts per group) were randomly chosen for harvesting bilateral ovaries $2 \mathrm{~h}$ after the morning meal under anaesthesia. Cumulus-oocyte complex (COC) and follicular fluid samples were also collected from antral follicles (diameter $1-3 \mathrm{~mm}$ ) on the surface of ovaries, as previously described [18], snap-frozen, and stored at $-80^{\circ} \mathrm{C}$. At $19 \mathrm{~d}$ of the 2nd oestrous cycle, another 24 gilts ( 6 gilts per group) were slaughtered for collecting ovarian, oviduct and uterine samples. Ovaries were washed with PBS prewarmed at $39{ }^{\circ} \mathrm{C}$, maintained at $39^{\circ} \mathrm{C}$ in TCM199 medium (Gibco, USA) containing $0.1 \%$ polyvinyl alcohol (Sigma, USA), and transported to the laboratory within $1 \mathrm{~h}$ after sample collection. Uterus and oviduct samples were washed with ice-cooled PBS and dried with sterile tissue paper, and their weight and length in both directions (left and right) were measured.

Colonic contents at the proximal section were quickly transferred to $1.5-\mathrm{mL}$ sterile tubes, washed 3 times with ice-cold PBS, and dried with sterile tissue paper. Both colonic tissues and contents were snap-frozen in $\mathrm{N}_{2}$ and stored at $-80^{\circ} \mathrm{C}$.

\section{Oocyte maturation in vitro}

COCs collected from follicles with diameters between 3 $\mathrm{mm}$ and $6 \mathrm{~mm}$ at $19 \mathrm{~d}$ of the 2nd oestrous cycle were subjected to in vitro maturation to measure their oocyte quality as previously described with minor modifications [18]. In brief, COCs were aspirated from large follicles with a $10-\mathrm{mL}$ syringe equipped with an 18-gauge needle on a sterile operating table. COCs were carefully collected under a stereo microscope (Olympus, Japan), and only those with uniform oocyte cytoplasm and at least 2 layers of cumulus cells were selected for culture and maturation in vitro. Follicular fluid was harvested by centrifuging at $3000 \times g$ at $4{ }^{\circ} \mathrm{C}$ and stored at $-20^{\circ} \mathrm{C}$ for future analysis. The in vitro maturation medium was based on TCM199 medium, which was supplemented with $0.1 \%$ polyvinyl alcohol (Sigma), $10 \%$ porcine follicular fluid (from COCs with a diameter $\geq 3 \mathrm{~mm}$ ), 3.05 $\mathrm{mmol} / \mathrm{L} \mathrm{D}$-glucose (Sigma), $0.91 \mathrm{mmol} / \mathrm{L}$ sodium pyruvate (Sigma), 1× Penicillin-Streptomycin solution (Sigma), $0.57 \mathrm{mmol} / \mathrm{L}$ Cysteine (Sigma), $15 \mathrm{U} / \mathrm{mL} \mathrm{LH}$ (Prospec, Israel), $15 \mathrm{U} / \mathrm{mL}$ FSH (Prospec) and $10 \mathrm{ng} / \mathrm{mL}$ EGF (Prospec). Cumulus cell expansion was measured after $22 \mathrm{~h}$ of culture in vitro by determining the expansion of cumulus cells surrounding oocytes using the following scoring scheme: Score 0, no expansion of cumulus cells; Score 1, a slight expansion of the outer layer of cumulus cells; Score 2, expansion of the outer two-to-three layers of cumulus cells; Score 3, expansion of $50 \%$ of cumulus cells; Score 4, full expansion of cumulus cells. Finally, evaluation of cumulus expansion was calculated by the following equation: rate of cumulus expansion $(\%)=[$ total scores of COCs per gilt / (the number of COCs $\times 4$ )] $\times 100 \%$. Next, cumulus cells were removed from COCs by gentle vortexing in $0.1 \%$ hyaluronidase (Sigma) in TCM 199 after in vitro maturation for $44 \mathrm{~h}$, and the maturation of oocytes to metaphase II (MII) at $44 \mathrm{~h}$ of culture was evaluated based on the presence of the first polar body as previously described $[18,19]$.

\section{Analysis of SCFAs and microbiota}

Along with the colonic contents, levels of acetate, propionate and butyrate SCFAs in faecal samples at $30 \mathrm{~d}$ of the experiment and at $19 \mathrm{~d}$ of the 2nd oestrous cycle were determined using a Varian CP-3800 gas chromatograph (manual injection, flame ionisation detector, $10 \mu \mathrm{L}$ microinjector; Varian), as previously described [13]. Microbial diversity in faeces at $19 \mathrm{~d}$ of the 2 nd oestrous cycle was measured using high-throughput pyrosequencing (16S rRNA analysis). Detailed procedures were conducted as previously described [10], and they are presented in the online supplementary methods.

\section{Measurement of serotonin and melatonin}

The concentrations of serotonin (DLD Diagnostika $\mathrm{GmbH}$ ) and melatonin (IBL \#RE54021) in serum and follicular fluid samples were measured with their respective ELISA kits as recently described [13]. Additionally, the serotonin content in proximal colon tissues was normalised to tissue weight. 


\section{Gene expression}

Gene expression in ovarian COCs was investigated by real-time PCR. In brief, RNA was extracted with TRIzol reagent (TaKaRa, Dalian, China) for the synthesis of cDNA using a commercial reverse transcription kit (TaKaRa) was used. A 7900HT Fast Real-Time PCR System (Thermo Fisher Scientific) with SYBR Green RealTime PCR reagent (RR820A, TaKaRa) was used to measure mRNA levels. Primers for target genes were bone morphogenetic protein 15 (BMP15) forward 5'-AGCT TCCACCAACTGGGTTGG-3' and reverse 5' -TCATCT GCATGTACAGGGCTG-3', growth differentiation factor 9 (GDF9) forward 5'-GGTATGGCTCTCCGGTTC ACAC-3' and reverse 5' - CTTGGCAGGTACGCAGGA TGG-3', $\beta$-actin, forward 5'-GGCCGCACCACTGGCA TTGTCAT and reverse $5^{\prime}$ - AGGTCCAGACGCAGGA TGGCG-3'. The threshold cycle $\left(2^{-\Delta \Delta C t}\right)$ method was used to calculate relative gene expression. $\beta$-actin was used as the housekeeping gene, and relative gene expression levels are expressed as fold changes relative to those in the DF 1.0 group.

\section{Untargeted metabolomics}

Sera from 8 gilts per group were used for untargeted metabolomics analysis. In each group, 2 serum samples were randomly pooled as one sample, resulting in 4 replicate samples for each group. The detailed procedures, including metabolite extraction, UHPLC-MS/MS analysis, database search, and data analysis are presented in the online supplementary materials.

\section{Statistical analysis}

Raw data were checked using the Grubb's test method. If $|X p-X|>\lambda(\alpha, n) S$, then $X p$ was considered an outlier. Measurement data were normally distributed after testing for homogeneity of variance and normal distribution using the Shapiro-Wilk method in SAS 9.4 (SAS Institute Inc., Cary, NC, USA). As a completely randomised design, the statistical analyses were performed through the mixed procedure of SAS 9.4 using the following statistical model: $Y i j=\mu+T i+e i j$, where $Y$ is the analysed variable, $\mu$ is the overall mean, $T i$ is the fixed effect of the $i$ th treatment, and $e i j$ is the error term specific to the pig identified assigned to the $i$ th treatment. The linear and quadratic effects of increasing DF levels on the analysed variable were determined by orthogonal polynomial contrast. Differences were considered statistically significant when $P<0.05$ and a trend was considered significant when $0.05 \leq P<0.10$.

\section{Results}

Nutrient intake and number of gilts at each stage Six gilts per group were removed from the experiment after collection of their ovaries at $30 \mathrm{~d}$ of the experiment, 13 gilts remained per group from $31 \mathrm{~d}$ of the experiment. Additionally, 9 gilts (4, 2, 2 and 1 in DF 1.5, DF 1.75 and DF 2.0, respectively) were excluded since they did not show oestrous at 240 days of age. In this study, gilts in each treatment group could consume their provided feed; therefore, gilts in each group were expected to consume similar levels of digestible energy, amino acids, minerals and vitamins, but with different levels of DF intake. The estimated average daily DF intake was $284.28 \mathrm{~g} / \mathrm{d}, 420.92 \mathrm{~g} / \mathrm{d}, 494.91 \mathrm{~g} / \mathrm{d}$ and $568.16 \mathrm{~g} /$ $\mathrm{d}$ for DF 1.0, DF 1.5, DF 1.75 and DF 2.0 groups, respectively, throughout the experimental period. The average daily gain in body weight at $30 \mathrm{~d}$ of experiment and at $19 \mathrm{~d}$ of the 2 nd oestrous cycle were reported in a companion study [7], and were not affected by dietary treatment.

\section{Effects of DF intake level on oocyte quality and reproductive organ development}

As shown in Table 2, the number of COCs collected per gilt ranged between 21.2 and 23.3, and the number of oocytes used for in vitro maturation ranged between 15.5 and 15.7, and these were not affected by DF intake level $(P>0.05)$. The expansion rate of COCs was not affected by DF level $(P>0.05)$. The rate of oocytes with first polar bodies increased linearly with increasing DF level $(P=0.001)$, and was significantly higher for the DF 1.75 diet than for the DF 1.0 diet $(57.5 \%$ vs. $37.7 \%$, $P<0.05)$. The mRNA expression levels of GDF-9 and $B M P-15$, two markers of oocyte quality in ovarian COCs of gilts (Fig. 2a-d), were increased linearly with increasing DF intake level at $30 \mathrm{~d}$ of the experiment and $19 \mathrm{~d}$ of the 2nd oestrous cycle.

The effects of DF intake level on the development of reproductive organs (uterus and oviduct) are shown in Table 3. The weight of the uterus $(P=0.059)$ and the relative weight of the uterus $(P=0.017)$ increased linearly with increasing DF intake level. The relative weight of the uterus in gilts increased from $5.44 \mathrm{~g} / \mathrm{kg}$ $\mathrm{BW}$ in the DF 1.0 group to $6.21 \mathrm{~g} / \mathrm{kg} \mathrm{BW}$ in the DF 1.75 group $(P<0.05)$. The lengths of the left uterine horn $(P=0.044)$ and the right uterine horn $(P=0.001)$ were increased by DF intake level. Specifically, DF 1.75 gilts had a $19.8 \%$ greater oocyte maturation rate and a 48.9 $\mathrm{cm}$ longer uterus length than DF 1.0 gilts $(P<0.05)$. The weight of the left oviduct $(P=0.087)$ and the right oviduct $(P=0.002)$ increased linearly with increasing DF intake level.

\section{Effects of DF intake level on faecal microbial diversity at $19 \mathrm{~d}$ of the 2 nd oestrous cycle}

Total tags, unique tags, taxon tags, and operational taxonomic units (OTUs) of faecal microbiota at $19 \mathrm{~d}$ of the 2nd oestrous cycle in the 4 dietary groups were 
Table 2 Effects of DF intake level on oocyte maturation in gilts

\begin{tabular}{|c|c|c|c|c|c|c|}
\hline \multirow[t]{2}{*}{ Items } & \multicolumn{4}{|l|}{ Treatments } & \multicolumn{2}{|c|}{$P$-value } \\
\hline & DF 1.0 & DF 1.5 & DF 1.75 & DF 2.0 & Linear & Quadratic \\
\hline No. of COCs collected per gilt & $23.3 \pm 1.4$ & $21.2 \pm 1.2$ & $22.2 \pm 0.9$ & $22.5 \pm 2.3$ & 0.695 & 0.403 \\
\hline No. of oocytes for in vitro maturation & $15.5 \pm 0.2$ & $15.7 \pm 0.2$ & $15.7 \pm 0.2$ & $15.5 \pm 0.2$ & 0.898 & 0.467 \\
\hline Expansion rate, \% & $86.9 \pm 5.9$ & $89.5 \pm 3.5$ & $91.5 \pm 2.1$ & $93.6 \pm 3.3$ & 0.232 & 0.876 \\
\hline Rate of oocytes with first polar body, $\%$ & $37.7 \pm 3.2^{c}$ & $41.6 \pm 3.0^{\mathrm{bc}}$ & $57.5 \pm 2.5^{\mathrm{a}}$ & $50.6 \pm 2.3^{\mathrm{ab}}$ & 0.001 & 0.568 \\
\hline
\end{tabular}

Data are expressed as means \pm standard error (S.E.); $D F$, dietary fiber; $n=6$; Means with different letters ${ }^{\text {a,b,c }}$ denote $P<0.05$

$1,721,847,242,996,1,478,851$ and 31,092, respectively, at the $97 \%$ identity level, revealed by $16 \mathrm{~S}$ rRNA sequencing. Microbiota alpha diversity was reflected by observed species, Shannon and Chao 1 indices. The observed species and Shannon indices were similar for DF 1.5 and DF 1.0 groups, but were lower than those of the DF 1.75 and DF 2.0 groups (Fig. $3 a$ and $b, P<0.05$ ). The Chao 1 index for the DF 1.5 group was lower than for the DF 1.0, DF 1.75 and DF 2.0 groups (Fig. 3c, $P<0.05$ ).

As shown in the heatmap in Supplementary Fig. 1a and $b$, we identified clear differences in the phylum and genus distributions of faecal microbiota with increasing DF intake level. The relative abundances of microbiota at the phylum level in faeces of gilts at $19 \mathrm{~d}$ of the 2 nd oestrous cycle are presented in Table 4. Two dominant phyla, Firmicutes and Bacteroidetes, accounted for $85 \%$ of faecal microbiota. The relative abundance of the Firmicutes phylum decreased linearly $(P<0.001)$ or quadratically $(P=0.003)$ with increasing DF intake level. By contrast, the relative abundance of the Bacteroidetes phylum increased linearly $(P<0.001)$ or quadratically $(P=0.043)$ by increasing DF intake level. The relative abundance of the Proteobacteria phylum decreased linearly with increasing DF intake level $(P=0.002)$. The relative abundance of Tenericutes increased linearly with increasing DF intake level $(P=0.002)$. The relative abundance of the Actinobacteria and Planctomycetes phyla decreased linearly $(P<0.001)$ or quadratically $(P<0.05)$

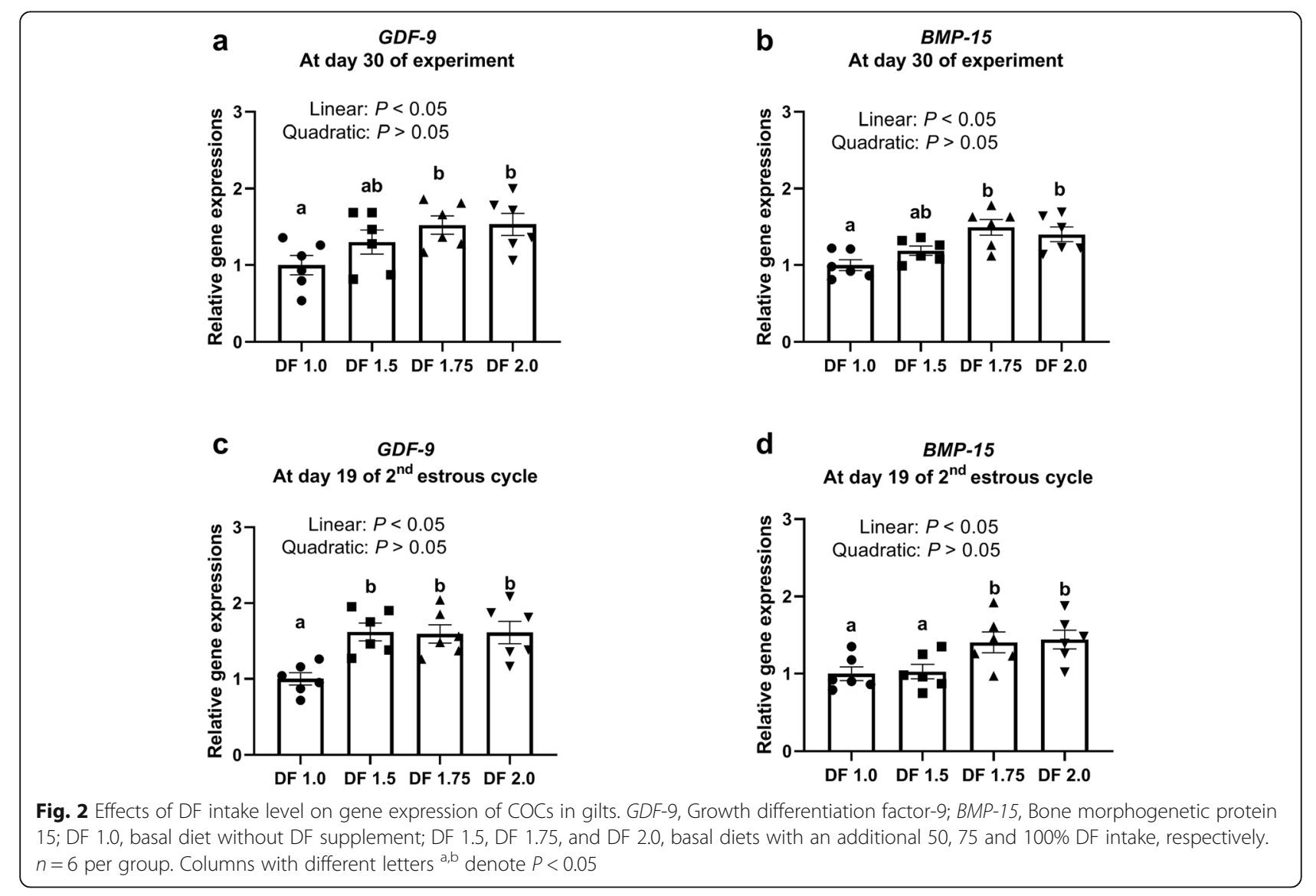


Table 3 Effects of DF intake level on the development of reproductive tracts in gilts

\begin{tabular}{|c|c|c|c|c|c|c|}
\hline \multirow[t]{2}{*}{ Items } & \multicolumn{4}{|l|}{ Treatments } & \multicolumn{2}{|c|}{$P$-value } \\
\hline & DF 1.0 & DF 1.5 & DF 1.75 & DF 2.0 & Linear & Quadratic \\
\hline BW at laughter, kg & $146.7 \pm 1.6$ & $145.3 \pm 1.8$ & $145.8 \pm 3.0$ & $142.3 \pm 1.7$ & 0.209 & 0.549 \\
\hline Weight of uterus, kg & $0.80 \pm 0.02$ & $0.82 \pm 0.02$ & $0.90 \pm 0.03$ & $0.84 \pm 0.02$ & 0.059 & 0.380 \\
\hline Relative weight of uterus, $\mathrm{g} / \mathrm{kg}$ & $5.44 \pm 0.17^{b}$ & $5.64 \pm 0.16^{\mathrm{ab}}$ & $6.21 \pm 0.22^{\mathrm{a}}$ & $5.91 \pm 0.14^{\mathrm{ab}}$ & 0.017 & 0.548 \\
\hline Left uterine, cm & $99.2 \pm 4.3^{b}$ & $107.3 \pm 3.3^{\mathrm{ab}}$ & $118.2 \pm 5.3^{\mathrm{a}}$ & $109.2 \pm 5.3^{\mathrm{ab}}$ & 0.044 & 0.232 \\
\hline Right uterine, $\mathrm{cm}$ & $91.8 \pm 4.2^{c}$ & $99.3 \pm 3.1^{\mathrm{bc}}$ & $121.7 \pm 6.3^{\mathrm{a}}$ & $113.5 \pm 6.0^{\mathrm{ab}}$ & 0.001 & 0.660 \\
\hline Left oviduct, g & $3.93 \pm 0.25$ & $4.02 \pm 0.47$ & $5.19 \pm 0.36$ & $4.64 \pm 0.50$ & 0.087 & 0.880 \\
\hline Right oviduct, g & $3.63 \pm 0.22^{b}$ & $4.12 \pm 0.54^{b}$ & $5.91 \pm 0.30^{\mathrm{a}}$ & $4.97 \pm 0.38^{\mathrm{ab}}$ & 0.002 & 0.446 \\
\hline Left oviduct, cm & $30.5 \pm 0.9$ & $33.3 \pm 2.6$ & $35.3 \pm 1.0$ & $33.8 \pm 1.7$ & 0.100 & 0.400 \\
\hline Right oviduct, $\mathrm{cm}$ & $30.6 \pm 1.1$ & $32.7 \pm 2.5$ & $36.5 \pm 1.2$ & $33.2 \pm 2.1$ & 0.123 & 0.343 \\
\hline
\end{tabular}

Data are expressed as means \pm S.E.; $D F$, dietary fiber; $n=6$; Means with different letters ${ }^{\text {a,b }}$ denote $P<0.05$

with increasing DF intake level. The relative abundance of Cyanobacteria increased linearly $(P<0.001)$ or quadratically $(P=0.01)$ with increasing DF intake level.

The relative abundances of microbiota at the genus level $(>0.1 \%)$ are presented in Table 5 . Thirty of the 53 genera increased linearly or quadratically changed with increasing DF intake level $(P<0.05$ or $P<0.01)$. The relative abundances of the genera Lactobacillus, Prevotella_9, Rikenellaceae_RC9_gut_group, Alloprevotella, Prevotellaceae_UCG-003, Prevotella_7, dgA-11_gut_ group, Sphaerochaeta, Leeia, Erysipelotrichaceae_UCG004, Catenibacterium, Fibrobacter and Faecalibacterium were elevated by increasing DF intake level (linear or quadratic, $P<0.05)$. The relative abundances of the genera Streptococcus, Clostridium_sensu_stricto_1, Succinivibrio, Eubacterium_coprostanoligenes_group, Ruminococcaceae NK4A214_group, Lachnospiraceae_XPB1014_group, Phascolarctobacterium, Escherichia-Shigella, Family_XIII_ AD3011_group, Turicibacter, Lachnospiraceae_AC2044_ group, Candidatus_Soleaferrea, Lachnospira, Blautia, Acidaminococcus, Romboutsia, and Lachnoclostridium decreased with increasing DF intake level (linear or quadratic, $P<0.05)$.
Effects of DF intake level on serum metabolomics at 19 $d$ of the 2nd oestrous cycle.

As presented in Fig. 4, the principal component analysis (PCA) score plot of serum metabolomics data from both positive (a) and negative (b) ionisation modes showed a clear separation of metabolite communities between gilts in DF 1.0 and other groups, and differentially altered metabolites revealed significant changes in hierarchical clustering (Supplementary Fig. 2a and b). The numbers of differentially abundant metabolites identified and annotated in serum samples between groups are presented in Supplementary Table 1, revealing 92, 123 and 171 differentially altered metabolites in DF 1.5, DF 1.75 and DF 2.0 gilts compared with DF 1.0 gilts.

In particular, we compared differentially abundant serum metabolites identified in both positive and negative ionisation modes between DF 1.0 and DF 1.75 gilts (Table 6). In brief, a total of 41 (in positive ionisation mode) and 20 (in negative ionisation mode) serum metabolites were upregulated by 1.5-27.0 times in DF 1.75 gilts compared with DF 1.0 gilts $(P<0.05$ or $P<0.01)$. A total of 25 (in positive ionisation mode) and 36 (in negative ionisation mode) serum metabolites were down-regulated in DF 1.75 gilts compared with DF 1.0
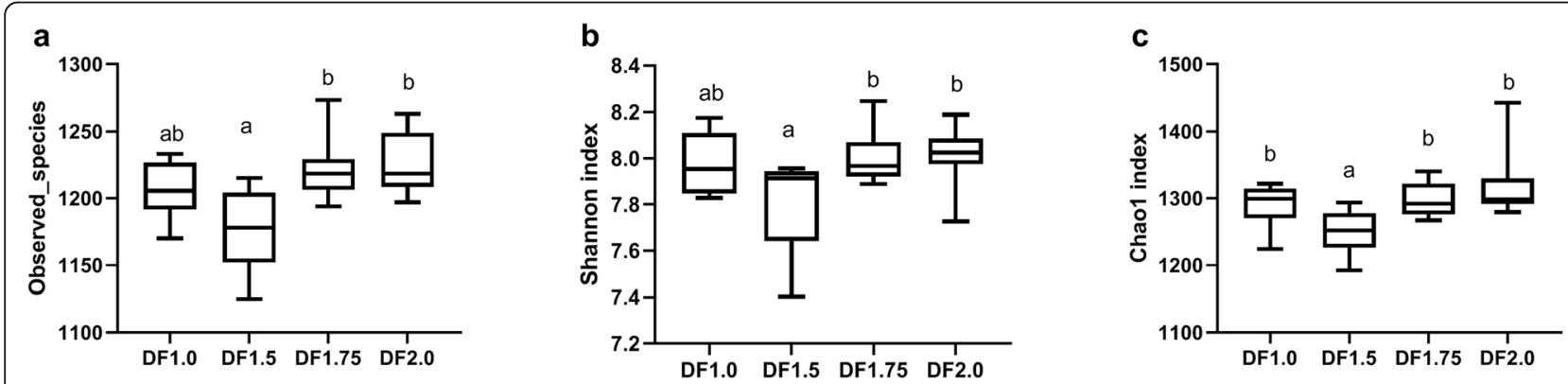

Fig. 3 Microbiota alpha-diversity in faeces of gilts fed different dietary fiber levels at $19 \mathrm{~d}$ of the 2nd oestrous cycle. a, Observed species. b, Shannon index. C, Chao 1 index. Gilts constituted the experimental units $(n=6)$. DF 1.0, basal diet without DF supplement; DF 1.5, DF 1.75 and DF 2.0, basal diets with an additional 50\%,75\% and 100\% DF intake, respectively. Columns with different letters ${ }^{\text {a,b }}$ denote $P<0.05$ 
Table 4 Relative abundance of microbiota at the phyla level in faeces of gilts, \%

\begin{tabular}{|c|c|c|c|c|c|c|}
\hline \multirow[t]{2}{*}{ Items } & \multicolumn{4}{|l|}{ Treatments } & \multicolumn{2}{|l|}{$P$-value } \\
\hline & $1.0 \mathrm{DF}$ & 1.5 DF & $1.75 \mathrm{DF}$ & $2.0 \mathrm{DF}$ & Linear & $\overline{\text { Quadratic }}$ \\
\hline Firmicutes & $44.22 \pm 1.07^{\mathrm{ab}}$ & $47.63 \pm 1.89^{a}$ & $40.34 \pm 1.53^{b c}$ & $38.36 \pm 0.80^{c}$ & $<0.001$ & 0.003 \\
\hline Bacteroidetes & $40.64 \pm 1.16^{b c}$ & $38.81 \pm 1.79^{c}$ & $44.85 \pm 1.78^{\mathrm{ab}}$ & $46.51 \pm 1.42^{\mathrm{a}}$ & 0.004 & 0.043 \\
\hline Spirochaetes & $4.62 \pm 0.65^{\mathrm{ab}}$ & $3.29 \pm 0.59^{b}$ & $5.76 \pm 0.63^{a}$ & $5.60 \pm 0.79^{\mathrm{ab}}$ & 0.169 & 0.079 \\
\hline Proteobacteria & $4.08 \pm 0.41^{a}$ & $3.80 \pm 0.26^{\mathrm{ab}}$ & $3.00 \pm 0.23^{b}$ & $3.00 \pm 0.24^{b}$ & 0.002 & 0.629 \\
\hline Tenericutes & $2.12 \pm 0.13$ & $2.26 \pm 0.27$ & $2.73 \pm 0.22$ & $2.69 \pm 0.16$ & 0.013 & 0.866 \\
\hline Euryarchaeota & $2.15 \pm 0.32$ & $2.72 \pm 0.79$ & $1.38 \pm 0.38$ & $1.97 \pm 0.29$ & 0.385 & 0.778 \\
\hline Actinobacteria & $0.87 \pm 0.55^{\mathrm{a}}$ & $0.22 \pm 0.01^{b}$ & $0.18 \pm 0.02^{b}$ & $0.23 \pm 0.03^{b}$ & $<0.001$ & 0.008 \\
\hline Lentisphaerae & $0.74 \pm 0.05^{\mathrm{b}}$ & $0.67 \pm 0.07^{b}$ & $1.02 \pm 0.08^{\mathrm{a}}$ & $0.82 \pm 0.07^{\mathrm{ab}}$ & 0.062 & 0.840 \\
\hline Planctomycetes & $0.13 \pm 0.04^{\mathrm{ab}}$ & $0.26 \pm 0.09^{a}$ & $0.09 \pm 0.02^{b}$ & $0.05 \pm 0.01^{b}$ & 0.017 & 0.002 \\
\hline Cyanobacteria & $0.17 \pm 0.02^{b c}$ & $0.15 \pm 0.02^{c}$ & $0.25 \pm 0.04^{\mathrm{ab}}$ & $0.34 \pm 0.05^{\mathrm{a}}$ & $<0.001$ & 0.010 \\
\hline Others & $0.25 \pm 0.03^{b}$ & $0.18 \pm 0.01^{c}$ & $0.41 \pm 0.02^{\mathrm{a}}$ & $0.47 \pm 0.05^{\mathrm{a}}$ & $<0.001$ & $<0.001$ \\
\hline
\end{tabular}

Data are expressed as means \pm S.E.; $D F$, dietary fiber; $n=6$; Means with different letters ${ }^{\text {a,b }}$ denote $P<0.05$

gilts $(P<0.05$ or $P<0.01)$. Enrichment of these metabolites resulted in changes in multiple biological pathways (Fig. 5), including the serotonergic pathway, the PPAR signalling pathway, Parkinson's disease, carbohydrate digestion and absorption, arachidonic acid metabolism, protein digestion and absorption, propanoate metabolism, inflammatory mediator regulation of TRP channels, cholesterol metabolism, bile secretion, pyrimidine metabolism, oxidative phosphorylation, fatty acid biosynthesis, nicotinate and nicotinamide metabolism, neuroactive ligand-receptor interaction, and metabolic pathways under positive ionisation mode (Fig. 5a), and sphingolipid metabolism, alanine, aspartate and glutamate metabolism, lysine degradation, folate biosynthesis, metabolic pathways, arginine and proline metabolism, beta-alanine metabolism, purine metabolism, glutathione metabolism, $\mathrm{ABC}$ transporters, and bile secretion under negative ionisation mode (Fig. 5b).

The effects of DF intake level on concentrations of SCFAs in faeces and colon chyme of gilts are shown in Table 7. The concentrations of acetate, propionate and butyrate in faeces of gilts on $30 \mathrm{~d}$ of the experiment were linearly increased by DF intake level $(P<0.05$ or $P<0.01$, Table 7$)$. The concentrations of propionate and butyrate in chyme in the colons of gilts at $19 \mathrm{~d}$ of the 2 nd oestrous cycle were linearly increased by DF intake level $(P<0.05$, Table 7).

The effects of DF intake level on serotonin concentrations in the serum and follicular fluid in gilts are presented in Table 8. The serum serotonin concentrations on $30 \mathrm{~d}$ of the experiment increased linearly with increasing DF intake level $(P=0.001$, Table 8$)$. The elevation in DF intake level resulted in a linear increase in serotonin in serum $(P<0.001$, Table 8$)$ and in follicular fluid $(P=0.032$, Table 8$)$.
Melatonin concentrations in follicular fluid increased linearly with increasing DF intake level at $30 \mathrm{~d}$ of the experiment and at $19 \mathrm{~d}$ of the 2 nd oestrous cycle (Supplementary Fig. 3).

Linear regression analysis results between butyrate concentration in colon chyme and serotonin in serum, follicular fluid, and colon tissues are presented in Table 9. A positive linear association was observed between butyrate concentration in colon chyme and serotonin in serum, follicular fluid and colon tissues $(P<0.01$, Table 9$)$.

\section{Discussion}

DF is an anti-nutritional factor that exerts negative effects on nutrient digestion, and sometimes diminishes growth performance [20]. However, basal diet supplemented with graded amounts of DF from a $33 \mathrm{~kg}$ phase did not negatively impact growth performance and the age at puberty in gilts [7]. Oocyte maturation, a parameter reflecting the quality of oocytes, is a determining factor influencing early embryo development [21, 22]. Previous research revealed that the beneficial effects of fiber-rich ingredients on early embryonic survival could be attributed to enhanced oocyte maturation in gilts [5, 6]. Consistently, results from our recent studies demonstrated that DF could improve the survival rate of immature oocytes, thereby improving the ovarian reservation of replacement gilts $[7,13]$. The current findings, coupled with the results of a companion study [7], proved beneficial effects of DF on both the number and quality of oocytes in growing gilts. The quality of replacement gilts not only plays an important role in pubertal maturation, but also influences the lifetime fertility of sows [23]. The successful reproductive process of sows requires a continuous supply of mature oocytes and the secretion of reproductive hormones such 
Table 5 Relative abundance of the top 53 microbiota at the genus level ${ }^{1}, \%$

\begin{tabular}{|c|c|c|c|c|c|c|}
\hline \multirow[t]{2}{*}{ Items } & \multicolumn{4}{|l|}{ Treatments } & \multicolumn{2}{|l|}{$P$-value } \\
\hline & $1.0 \mathrm{DF}$ & $1.5 \mathrm{DF}$ & $1.75 \mathrm{DF}$ & $2.0 \mathrm{DF}$ & Linear & Quadratic \\
\hline Prevotellaceae_NK3B31_group & $6.33 \pm 0.37$ & $6.70 \pm 0.80$ & $6.34 \pm 0.65$ & $7.10 \pm 1.04$ & 0.440 & 0.895 \\
\hline Lactobacillus & $2.21 \pm 0.16^{c}$ & $2.60 \pm 0.46^{b c}$ & $4.98 \pm 1.10^{\mathrm{a}}$ & $3.81 \pm 0.32^{\mathrm{ab}}$ & $<0.001$ & 0.660 \\
\hline Prevotella_9 & $3.46 \pm 0.54^{\mathrm{ab}}$ & $2.52 \pm 0.30^{b}$ & $4.77 \pm 0.73^{\mathrm{a}}$ & $5.14 \pm 0.92^{\mathrm{a}}$ & 0.025 & 0.034 \\
\hline Treponema_2 & $4.23 \pm 0.63$ & $2.98 \pm 0.57$ & $4.94 \pm 0.58$ & $4.78 \pm 0.79$ & 0.368 & 0.119 \\
\hline Rikenellaceae_RC9_gut_group & $4.33 \pm 0.31^{b c}$ & $3.95 \pm 0.33^{c}$ & $5.61 \pm 0.34^{\mathrm{ab}}$ & $5.80 \pm 0.40^{\mathrm{a}}$ & 0.001 & 0.045 \\
\hline Streptococcus & $3.83 \pm 0.28^{b}$ & $5.90 \pm 0.56^{\mathrm{a}}$ & $3.50 \pm 0.50^{b}$ & $2.87 \pm 0.29^{b}$ & 0.027 & $<0.001$ \\
\hline Methanobrevibacter & $2.05 \pm 0.32$ & $2.66 \pm 0.79$ & $1.34 \pm 0.38$ & $1.89 \pm 0.28$ & 0.413 & 0.726 \\
\hline Ruminococcaceae_UCG-005 & $2.61 \pm 0.27$ & $3.16 \pm 0.37$ & $2.17 \pm 0.23$ & $2.15 \pm 0.21$ & 0.069 & 0.079 \\
\hline Clostridium_sensu_stricto_1 & $2.46 \pm 0.29^{\mathrm{a}}$ & $2.68 \pm 0.16^{\mathrm{a}}$ & $1.85 \pm 0.10^{b}$ & $1.49 \pm 0.11^{b}$ & $<0.001$ & 0.001 \\
\hline Parabacteroides & $2.32 \pm 0.26$ & $2.24 \pm 0.26$ & $2.27 \pm 0.24$ & $2.15 \pm 0.18$ & 0.620 & 0.895 \\
\hline Succinivibrio & $1.98 \pm 0.30^{\mathrm{a}}$ & $1.61 \pm 0.17^{\mathrm{ab}}$ & $1.00 \pm 0.12^{c}$ & $1.11 \pm 0.15^{b c}$ & $<0.001$ & 0.845 \\
\hline Megasphaera & $1.88 \pm 0.36$ & $1.85 \pm 0.69$ & $0.87 \pm 0.17$ & $1.30 \pm 0.50$ & 0.089 & 0.838 \\
\hline Ruminococcaceae_UCG-002 & $2.42 \pm 0.21$ & $2.36 \pm 0.21$ & $2.30 \pm 0.12$ & $2.46 \pm 0.24$ & 0.989 & 0.571 \\
\hline Eubacterium_coprostanoligenes_group & $2.06 \pm 0.08^{\mathrm{a}}$ & $2.42 \pm 0.22^{\mathrm{a}}$ & $1.58 \pm 0.15^{b}$ & $1.51 \pm 0.08^{b}$ & 0.001 & 0.001 \\
\hline Prevotellaceae_UCG-001 & $1.54 \pm 0.37$ & $1.24 \pm 0.22$ & $1.27 \pm 0.34$ & $1.67 \pm 0.38$ & 0.934 & 0.212 \\
\hline Ruminococcaceae_NK4A214_group & $1.43 \pm 0.08^{\mathrm{ab}}$ & $1.50 \pm 0.12^{\mathrm{a}}$ & $1.18 \pm 0.10^{b}$ & $1.16 \pm 0.06^{b}$ & 0.008 & 0.169 \\
\hline Oscillospira & $1.42 \pm 0.08$ & $1.32 \pm 0.09$ & $1.42 \pm 0.14$ & $1.41 \pm 0.07$ & 0.944 & 0.532 \\
\hline Ruminococcaceae_UCG-014 & $1.36 \pm 0.14$ & $1.31 \pm 0.12$ & $1.12 \pm 0.12$ & $1.18 \pm 0.11$ & 0.149 & 0.922 \\
\hline Alloprevotella & $1.34 \pm 0.13$ & $1.28 \pm 0.24$ & $1.69 \pm 0.14$ & $1.92 \pm 0.20$ & 0.027 & 0.188 \\
\hline Prevotellaceae_UCG-003 & $1.28 \pm 0.09^{b c}$ & $1.25 \pm 0.20^{c}$ & $1.97 \pm 0.15^{\mathrm{a}}$ & $1.88 \pm 0.17^{\mathrm{ab}}$ & 0.002 & 0.382 \\
\hline Lachnospiraceae_XPB1014_group & $1.12 \pm 0.11$ & $1.13 \pm 0.08$ & $0.94 \pm 0.08$ & $0.85 \pm 0.06$ & 0.011 & 0.191 \\
\hline Prevotella_1 & $1.00 \pm 0.09$ & $0.77 \pm 0.10$ & $0.79 \pm 0.14$ & $0.96 \pm 0.14$ & 0.680 & 0.095 \\
\hline Ruminococcus_1 & $0.98 \pm 0.08$ & $1.03 \pm 0.16$ & $0.82 \pm 0.09$ & $0.88 \pm 0.10$ & 0.271 & 0.710 \\
\hline Phascolarctobacterium & $0.87 \pm 0.09^{\mathrm{a}}$ & $1.10 \pm 0.16^{\mathrm{a}}$ & $0.60 \pm 0.06^{b}$ & $0.57 \pm 0.03^{b}$ & $<0.001$ & 0.010 \\
\hline Prevotella_2 & $0.81 \pm 0.08$ & $0.66 \pm 0.10$ & $1.01 \pm 0.12$ & $1.04 \pm 0.09$ & 0.055 & 0.080 \\
\hline Ruminococcaceae_UCG-010 & $0.71 \pm 0.04$ & $0.67 \pm 0.08$ & $0.76 \pm 0.03$ & $0.81 \pm 0.05$ & 0.147 & 0.256 \\
\hline Prevotella_7 & $0.66 \pm 0.13$ & $0.36 \pm 0.06$ & $0.78 \pm 0.15$ & $0.89 \pm 0.21$ & 0.154 & 0.010 \\
\hline Christensenellaceae_R-7_group & $0.60 \pm 0.06$ & $0.68 \pm 0.06$ & $0.50 \pm 0.04$ & $0.52 \pm 0.04$ & 0.093 & 0.168 \\
\hline Escherichia-Shigella & $0.56 \pm 0.22^{\mathrm{a}}$ & $0.37 \pm 0.09^{\mathrm{ab}}$ & $0.15 \pm 0.02^{c}$ & $0.23 \pm 0.05^{b c}$ & $<0.001$ & 0.304 \\
\hline dgA-11_gut_group & $0.52 \pm 0.08$ & $0.52 \pm 0.07$ & $0.68 \pm 0.06$ & $0.82 \pm 0.12$ & 0.008 & 0.179 \\
\hline Family_XII_AD3011_group & $0.50 \pm 0.03^{\mathrm{a}}$ & $0.48 \pm 0.05^{\mathrm{ab}}$ & $0.39 \pm 0.02^{b}$ & $0.43 \pm 0.02^{\mathrm{ab}}$ & 0.018 & 0.734 \\
\hline Terrisporobacter & $0.53 \pm 0.05$ & $0.52 \pm 0.04$ & $0.67 \pm 0.08$ & $0.53 \pm 0.04$ & 0.541 & 0.492 \\
\hline Sphaerochaeta & $0.39 \pm 0.03^{b}$ & $0.31 \pm 0.03^{b}$ & $0.76 \pm 0.10^{\mathrm{a}}$ & $0.79 \pm 0.04^{\mathrm{a}}$ & $<0.001$ & 0.001 \\
\hline Turicibacter & $0.33 \pm 0.06^{\mathrm{a}}$ & $0.33 \pm 0.02^{\mathrm{a}}$ & $0.23 \pm 0.02^{\mathrm{ab}}$ & $0.21 \pm 0.02^{b}$ & 0.001 & 0.212 \\
\hline Lachnospiraceae_AC2044_group & $0.34 \pm 0.02^{\mathrm{a}}$ & $0.29 \pm 0.01^{\mathrm{a}}$ & $0.18 \pm 0.02^{b}$ & $0.19 \pm 0.01^{b}$ & $<0.001$ & 0.764 \\
\hline Leeia & $0.23 \pm 0.04^{b}$ & $0.21 \pm 0.08^{b}$ & $0.68 \pm 0.27^{a}$ & $0.51 \pm 0.08^{\mathrm{ab}}$ & 0.002 & 0.534 \\
\hline Mitsuokella & $0.25 \pm 0.04$ & $0.28 \pm 0.09$ & $0.33 \pm 0.13$ & $0.25 \pm 0.04$ & 0.794 & 0.368 \\
\hline Candidatus_Soleaferrea & $0.22 \pm 0.01^{\mathrm{a}}$ & $0.25 \pm 0.03^{\mathrm{a}}$ & $0.13 \pm 0.01^{b}$ & $0.16 \pm 0.01^{b}$ & $<0.001$ & 0.207 \\
\hline Lachnospira & $0.20 \pm 0.03^{\mathrm{a}}$ & $0.19 \pm 0.01^{b}$ & $0.14 \pm 0.01^{b}$ & $0.14 \pm 0.01^{b}$ & $<0.001$ & 0.404 \\
\hline Blautia & $0.21 \pm 0.11^{\mathrm{a}}$ & $0.10 \pm 0.01^{\mathrm{ab}}$ & $0.09 \pm 0.02^{b}$ & $0.07 \pm 0.01^{b}$ & $<0.001$ & 0.526 \\
\hline Acidaminococcus & $0.18 \pm 0.05^{\mathrm{a}}$ & $0.17 \pm 0.08^{a}$ & $0.04 \pm 0.01^{b}$ & $0.08 \pm 0.03^{\mathrm{ab}}$ & 0.003 & 0.896 \\
\hline Ruminococcaceae_UCG-009 & $0.16 \pm 0.01$ & $0.15 \pm 0.02$ & $0.18 \pm 0.02$ & $0.17 \pm 0.01$ & 0.444 & 0.511 \\
\hline Romboutsia & $0.15 \pm 0.03^{\mathrm{a}}$ & $0.14 \pm 0.01^{\mathrm{a}}$ & $0.08 \pm 0.01^{\mathrm{b}}$ & $0.08 \pm 0.01^{\mathrm{b}}$ & $<0.001$ & 0.366 \\
\hline
\end{tabular}


Table 5 Relative abundance of the top 53 microbiota at the genus level ${ }^{1}, \%$ (Continued)

\begin{tabular}{|c|c|c|c|c|c|c|}
\hline \multirow[t]{2}{*}{ Items } & \multicolumn{4}{|l|}{ Treatments } & \multicolumn{2}{|l|}{$P$-value } \\
\hline & $1.0 \mathrm{DF}$ & $1.5 \mathrm{DF}$ & $1.75 \mathrm{DF}$ & $2.0 \mathrm{DF}$ & Linear & $\overline{\text { Quadratic }}$ \\
\hline Erysipelotrichaceae_UCG-004 & $0.14 \pm 0.02^{\mathrm{ab}}$ & $0.12 \pm 0.01^{b}$ & $0.18 \pm 0.02^{\mathrm{ab}}$ & $0.19 \pm 0.02^{\mathrm{a}}$ & 0.024 & 0.064 \\
\hline Catenibacterium & $0.14 \pm 0.03^{a}$ & $0.05 \pm 0.01^{b}$ & $0.19 \pm 0.06^{\mathrm{a}}$ & $0.25 \pm 0.06^{a}$ & 0.019 & $<0.001$ \\
\hline Bifidobacterium & $0.13 \pm 0.01$ & $0.11 \pm 0.01$ & $0.09 \pm 0.02$ & $0.14 \pm 0.03$ & 0.904 & 0.107 \\
\hline Dialister & $0.12 \pm 0.05$ & $0.08 \pm 0.02$ & $0.20 \pm 0.07$ & $0.21 \pm 0.08$ & 0.061 & 0.058 \\
\hline Fibrobacter & $0.12 \pm 0.02$ & $0.06 \pm 0.01$ & $0.18 \pm 0.02$ & $0.25 \pm 0.05$ & $<0.001$ & $<0.001$ \\
\hline Lachnoclostridium & $0.12 \pm 0.02$ & $0.12 \pm 0.02$ & $0.07 \pm 0.01$ & $0.06 \pm 0.01$ & $<0.001$ & 0.075 \\
\hline Thalassospira & $0.10 \pm 0.01$ & $0.20 \pm 0.12$ & $0.13 \pm 0.01$ & $0.12 \pm 0.01$ & 0.571 & 0.044 \\
\hline Acetitomaculum & $0.10 \pm 0.02$ & $0.09 \pm 0.02$ & $0.12 \pm 0.02$ & $0.13 \pm 0.03$ & 0.178 & 0.457 \\
\hline Campylobacter & $0.08 \pm 0.01$ & $0.11 \pm 0.04$ & $0.09 \pm 0.02$ & $0.10 \pm 0.02$ & 0.751 & 0.595 \\
\hline Faecalibacterium & $0.08 \pm 0.01^{b c}$ & $0.07 \pm 0.01^{c}$ & $0.15 \pm 0.02^{\mathrm{a}}$ & $0.12 \pm 0.01^{\mathrm{ab}}$ & 0.004 & 0.475 \\
\hline
\end{tabular}

Data are expressed as means \pm S.E.; $D F$, dietary fiber; $n=6$; Means with different letters ${ }^{\text {a,b }}$ denote $P<0.05$

as oestrogen and progesterone from granulosa cells, which is largely determined by the number and quality of oocytes in ovaries [24-26]. Therefore, DF consumption during the replacement phase may exert a benefit on the lifetime fertility of sows, although this needs further validation.

Interestingly, our results implied that uterine development was also significantly promoted by DF intake level. To date, very few data are available on the nutrientdependent regulation of the uterus in gilts. Recent evidence found that dietary energy density and lysine level had no effect on uterine development [27]. Weaver et al. observed a $118 \mathrm{~g}$ heavier uterine weight on $19 \mathrm{~d}$ of the oestrous cycle in gilts fed a fiber-rich diet compared with a low-fiber diet [6]. The development of uterus at mating plays an important role in regulating early embryonic survival, since foetus would die if uterine endometrial lumen epithelium was insufficient to provide support to foetus development [28]. Therefore, replacement gilts fed a high DF diet during their rearing phase could benefit from subsequent improved fertility.
DF consists of nondigestible carbohydrates that are resistant to digestion and absorption in the porcine gastrointestinal tract. Hence their metabolism requires microbiota harboured in the gut. Indeed, microbial metabolism of DF is the key process mediating the beneficial effects of DF on gastrointestinal health and disease resistance $[17,29]$. DF significantly alters the gut microbial diversity of hosts, by stimulating the growth of fiberdegrading microbiota, and this alternation in gut microbial diversity in turn impacts gut microbial ecology, host physiology, and health [17, 29]. In order to investigate the role of microbiota in the regulation of oocyte maturation by dietary fiber, we explored microbial diversity by $16 \mathrm{~S}$ rRNA sequencing. In the present study, the Observed_species, Shannon index, and Chaol index of DF 1.5 gilts were lower than those of DF 1.75 and DF 2.0 groups, indicating that DF intake level altered the alpha diversity of microbiota in the gut. With increasing DF intake level, the relative abundance of 13 microbiota genera were significantly increased, among which
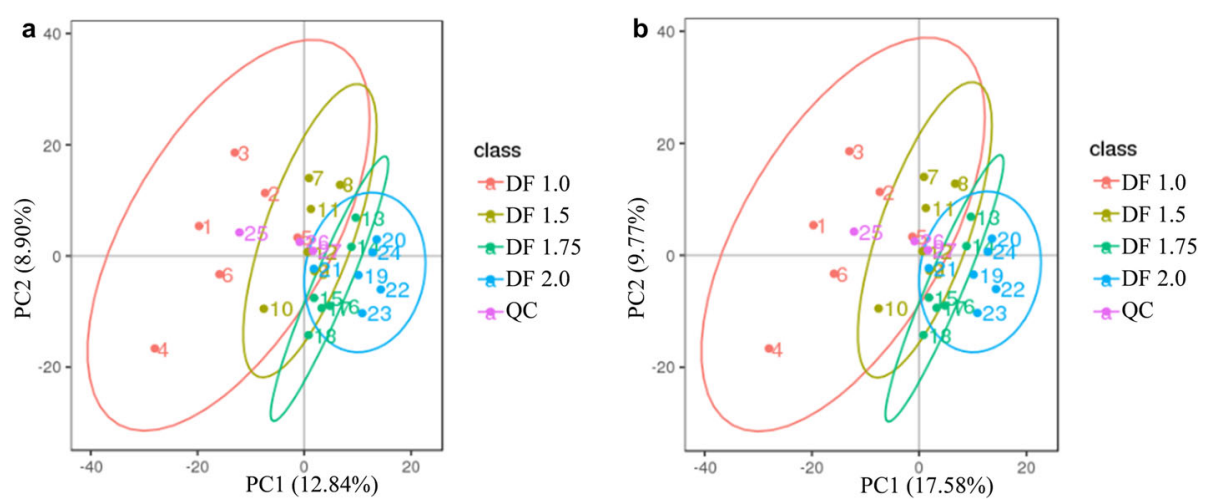

Fig. 4 Principal component analysis of the metabolites identified in positive and negative ionisation modes. DF 1.0, basal diet without DF supplement; DF 1.5, DF 1.75 and DF 2.0, basal diets with an additional 50\%, 75\% and 100\% DF intake, respectively. QC, quality control samples 
Table 6 Differentially abundant serum metabolites between DF 1.0 and DF 1.75 gilts identified in positive and negative ionisation modes $^{1,2}$

\begin{tabular}{|c|c|c|c|c|c|}
\hline Name & Fold change & $P$-value & Name & Fold change & $P$-value \\
\hline Positive ionisation & & & Negative ionisation & & \\
\hline $\begin{array}{l}\text { (2S)-1-Hydroxy-3-(pentadecanoyloxy)- } \\
\text { 2-propanyl (15Z)-15-tetracosenoate }\end{array}$ & 18.966 & 0.047 & Sinapyl alcohol & 27.041 & 0.044 \\
\hline $\begin{array}{l}\text { 3-(2,4-Cyclopentadien-1-ylidene)- } \\
\text { 5alpha-androstan-17beta-ol }\end{array}$ & 5.594 & 0.003 & Cuauhtemone & 13.210 & $<0.001$ \\
\hline Oxandrolone & 5.563 & 0.013 & Cholic acid glucuronide & 8.250 & 0.025 \\
\hline 2,6-Di-tert-butyl-1,4-benzoquinone & 5.028 & 0.005 & GLIMEPIRIDE, CIS- & 5.853 & $<0.001$ \\
\hline 19-Nortestosterone & 4.993 & 0.007 & Olivoretin D & 5.543 & 0.013 \\
\hline 3-Beta-fluoro-5-beta-pregnan-20-one & 4.670 & 0.002 & Deoxycholic acid & 4.117 & 0.001 \\
\hline p-Cymene & 4.148 & 0.008 & Avasimibe & 3.204 & 0.026 \\
\hline Geroquinol & 3.979 & 0.006 & Taurochenodeoxycholic acid & 3.100 & 0.044 \\
\hline Hypaphorine & 3.902 & $<0.001$ & p-Dimethylinamyl benzoate & 3.077 & $<0.001$ \\
\hline Jasmonal & 3.766 & 0.007 & Chaksine & 3.026 & 0.003 \\
\hline Ibuprofen & 3.680 & 0.002 & Tenivastatin & 2.962 & 0.009 \\
\hline 3-Beta,17-beta-diacetoxy-5a-androstane & 3.057 & 0.007 & Mupirocin & 2.918 & 0.047 \\
\hline Oleandomycin 2'-O-phosphate & 2.998 & 0.041 & Ubiquinone Q4 & 2.219 & 0.025 \\
\hline lonene & 2.869 & 0.049 & Sunitinib & 2.185 & 0.011 \\
\hline Diaziquone & 2.858 & $<0.001$ & (3alpha)-3-Hydroxycholan-24-oic acid & 2.054 & 0.042 \\
\hline 1-Piperideine & 2.857 & 0.004 & Ifetroban & 2.038 & 0.010 \\
\hline Myxalamid A & 2.801 & 0.045 & Maleimide & 1.918 & 0.012 \\
\hline Genistein & 2.584 & 0.011 & $5-\mathrm{HT}$ & 1.855 & 0.003 \\
\hline 7-Ketodeoxycholic acid & 2.434 & 0.023 & Uldazepam & 1.814 & 0.018 \\
\hline $\begin{array}{l}\text { 1-O-[4-(1H-indol-3-yl)butanoyl] } \\
\text {-beta-D-glucopyranose }\end{array}$ & 2.335 & 0.001 & Indole-3-carboxilic acid-O-sulphate & 1.690 & 0.019 \\
\hline Linagliptin & 2.278 & 0.017 & 6a-Prostaglandin 11 & 0.566 & 0.011 \\
\hline (KDO)2-lipid IVA & 2.096 & 0.045 & 3-Hydroxydecanoic acid & 0.548 & 0.021 \\
\hline 4-Aminobenzoic acid & 2.089 & 0.043 & 14,18-Dihydroxy-12-oxo-9,13,15-octadecatrienoic acid & 0.542 & $<0.001$ \\
\hline Spermidine & 1.964 & 0.026 & Cromoglicic acid & 0.531 & $<0.001$ \\
\hline Hexoprenaline & 1.902 & 0.005 & Nemonapride (JAN) & 0.526 & 0.044 \\
\hline Manumycin & 1.899 & 0.041 & Epithienamycin F & 0.519 & 0.010 \\
\hline N-Lactoyl ethanolamine phosphate & 1.888 & 0.002 & 10-Undecenoic acid & 0.508 & 0.010 \\
\hline Perphenazine enantate & 1.862 & 0.003 & Prunin & 0.502 & 0.010 \\
\hline $5-\mathrm{HIAA}$ & 1.856 & 0.002 & Leucodelphinidin & 0.497 & 0.001 \\
\hline TU4153400 & 1.831 & 0.036 & MFCD00065806 & 0.496 & 0.015 \\
\hline $\begin{array}{l}\text { 1-Octadecanoyl-2-[(15Z)- } \\
\text { tetracosenoyl]-sn-glycero-3-phosphocholine }\end{array}$ & 1.855 & 0.044 & 4,6,8-Trihydroxy-7-methoxy-3-methyl-3,4-dihydroisochromen-1-one & 0.494 & 0.029 \\
\hline Bikhaconitine & 1.850 & 0.007 & ARAMITE & 0.485 & 0.024 \\
\hline Cediranib & 1.797 & 0.002 & Uridine & 0.480 & 0.013 \\
\hline Callystatin A & 1.782 & 0.017 & N-Palmitoyl-L-phenylalanine & 0.463 & 0.014 \\
\hline Decoside & 1.690 & 0.005 & Cidofovir anhydrous & 0.460 & 0.004 \\
\hline $\begin{array}{l}\text { 5-methyltetrahydropteroyltri- } \\
\text { L-Glutamic acid }\end{array}$ & 1.677 & 0.012 & 3-Indoxyl sulphate & 0.448 & 0.002 \\
\hline $\begin{array}{l}\text { 2-(2-Carboxyethyl)-4-methyl- } \\
\text { 5-Pentyl-3-furoic acid }\end{array}$ & 1.640 & 0.012 & Butoctamide semisuccinate & 0.447 & 0.009 \\
\hline Trans-Anethole & 1.637 & 0.021 & Kukoamine A & 0.443 & 0.001 \\
\hline Saccharocin & 1.541 & 0.002 & Pyrophosphoric Acid & 0.433 & 0.033 \\
\hline 5-Phospho-beta-D-ribosylamine & 1.540 & 0.009 & 4-Phenolsulfonic acid & 0.429 & 0.046 \\
\hline Dehydrocholic acid & 1.50 & 0.013 & Geranyl phosphate & 0.412 & 0.043 \\
\hline Tritoqualine & 0.634 & 0.008 & Caftaric acid & 0.412 & 0.008 \\
\hline
\end{tabular}


Table 6 Differentially abundant serum metabolites between DF 1.0 and DF 1.75 gilts identified in positive and negative ionisation modes $^{1,2}$ (Continued)

\begin{tabular}{|c|c|c|c|c|c|}
\hline Name & Fold change & $P$-value & Name & Fold change & $P$-value \\
\hline Benzoyl cyanide & 0.628 & $<0.001$ & Disulfaton & 0.396 & 0.023 \\
\hline Ocaperidone & 0.622 & 0.012 & 4-(1,2-Dihydroxy-2-propanyl)-1-methyl-1,2-cyclohexanediol & 0.388 & 0.021 \\
\hline Monomethyl phosphate & 0.621 & 0.002 & Hydrogen bromide & 0.363 & $<0.001$ \\
\hline MFCD00056202 & 0.619 & 0.019 & (2-Hydroxy-2-oxido-1,3,2-dioxaphospholan-4-yl) methyl palmitate & 0.316 & 0.004 \\
\hline Minosaminomycin & 0.589 & 0.037 & Chloralodol & 0.228 & $<0.001$ \\
\hline Trametinib & 0.557 & 0.003 & Caprylic acid & 0.199 & 0.024 \\
\hline Premithramycin $\mathrm{A}^{\prime}$ & 0.550 & 0.004 & 1,3-Nonanediol acetate & 0.187 & 0.039 \\
\hline Alpha,alpha'-trehalose 6-mycolate & 0.546 & 0.005 & Retosiban & 0.170 & $<0.001$ \\
\hline $\begin{array}{l}\text { 1-stearoyl-2-arachidonoyl- } \\
\text { sn-glycero-3-phosphoserine }\end{array}$ & 0.521 & 0.033 & 3-Hydroxytridecanoic acid & 0.155 & 0.009 \\
\hline Phytosphingosine & 0.521 & 0.016 & Difluprednate & 0.126 & $<0.001$ \\
\hline Depe & 0.484 & 0.006 & Leukotriene B4 & 0.075 & $<0.001$ \\
\hline Azithromycin & 0.462 & 0.001 & Pentachlorophenol & 0.071 & $<0.001$ \\
\hline $\begin{array}{l}\text { 1-Stearoyl-2-docosahexanoyl- } \\
\text { sn-glycero-3-phosphocholine }\end{array}$ & 0.461 & 0.037 & 3,4,15-Triacetoxy-12,13-epoxytrichothec-9-en-8-yl 3-methylbutanoate & 0.055 & $<0.001$ \\
\hline Benzyl succinate & 0.458 & 0.003 & Nobiletin & 0.029 & $<0.001$ \\
\hline Ascidiacyclamide & 0.457 & 0.005 & & & \\
\hline $\begin{array}{l}\text { 1,2-Dioleoyl-sn-glycero-3-phospho- } \\
\text { N,N-dimethylethanolamine }\end{array}$ & 0.436 & 0.011 & & & \\
\hline 12-Deoxyoligomycin A & 0.433 & 0.011 & & & \\
\hline Terminalin & 0.420 & 0.036 & & & \\
\hline Digitoxin & 0.415 & 0.028 & & & \\
\hline Uroporphyrinogen IV & 0.362 & 0.009 & & & \\
\hline Vilazodone & 0.361 & 0.001 & & & \\
\hline $\begin{array}{l}\mathrm{N}, \mathrm{N} \text {-Bis(2-hydroxyethyl) } \\
\text { dodecanamide }\end{array}$ & 0.334 & 0.002 & & & \\
\hline $\begin{array}{l}\text { 1-Eicosyl-2-docosanoyl-sn-glycero-3- } \\
\text { phosphocholine }\end{array}$ & 0.307 & 0.042 & & & \\
\hline Emblicanin A & 0.275 & 0.007 & & & \\
\hline Phytolaccoside B & 0.221 & 0.025 & & & \\
\hline
\end{tabular}

Serum samples collected on $19 \mathrm{~d}$ of the 2 nd oestrous cycle. Metabolites with VIP $>1, P$-value $<0.05$, fold change $\geq 1.5$ or fold change $\leq 0.65$ were considered differential metabolites

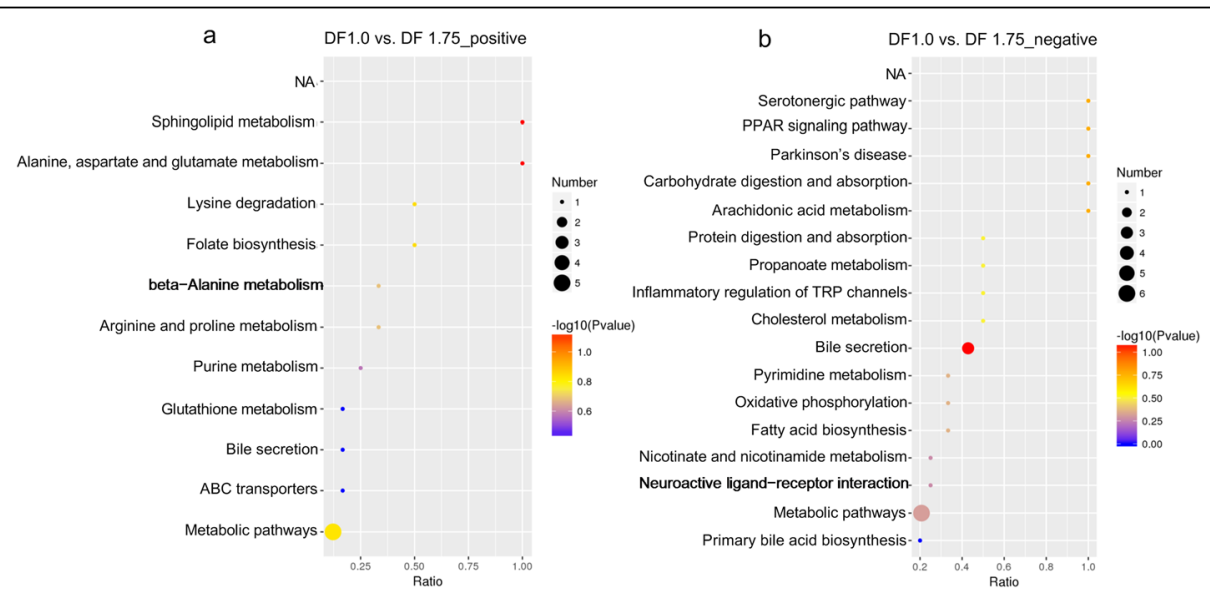

Fig. 5 KEGG pathway analysis of differential metabolites identified in positive and negative ionisation modes between DF 1.0 and DF 1.75 groups. DF 1.0, basal diet without DF supplement; DF 1.75, basal diet with an additional 75\% DF intake. DF, dietary fiber 
Table 7 Effects of DF intake level on the concentrations $(\mu \mathrm{mol} / \mathrm{g})$ of short-chain fatty acids in faeces and colon chyme of gilts

\begin{tabular}{|c|c|c|c|c|c|c|}
\hline \multirow[t]{2}{*}{ Items } & \multicolumn{4}{|l|}{ Treatments } & \multicolumn{2}{|l|}{$P$-value } \\
\hline & $1.0 \mathrm{DF}$ & $1.5 \mathrm{DF}$ & 1.75 DF & $2.0 \mathrm{DF}$ & Linear & Quadratic \\
\hline \multicolumn{7}{|c|}{${ }^{1}$ Faeces at $30 \mathrm{~d}$ of experiment } \\
\hline Acetate & $40.1 \pm 2.6^{b}$ & $41.5 \pm 2.9^{b}$ & $47.6 \pm 1.7^{\mathrm{ab}}$ & $51.4 \pm 2.7^{\mathrm{a}}$ & 0.002 & 0.231 \\
\hline Propionate & $14.2 \pm 1.6^{b}$ & $15.5 \pm 1.4^{\mathrm{ab}}$ & $19.2 \pm 0.8^{\mathrm{a}}$ & $19.4 \pm 1.1^{a}$ & 0.003 & 0.709 \\
\hline Butyrate & $8.4 \pm 0.8$ & $9.8 \pm 1.2$ & $11.4 \pm 1.1$ & $12.1 \pm 0.7$ & 0.010 & 0.843 \\
\hline \multicolumn{7}{|c|}{${ }^{2}$ Chyme in colon at $19 \mathrm{~d}$ of the 2 nd oestrous cycle } \\
\hline Acetate & $58.9 \pm 2.9$ & $56.8 \pm 4.8$ & $63.7 \pm 3.0$ & $62.6 \pm 3.0$ & 0.324 & 0.604 \\
\hline Propionate & $25.8 \pm 1.1$ & $24.8 \pm 1.9$ & $29.8 \pm 1.2$ & $31.8 \pm 3.5$ & 0.046 & 0.218 \\
\hline Butyrate & $11.6 \pm 0.4^{b}$ & $12.5 \pm 1.3^{\mathrm{ab}}$ & $13.1 \pm 0.8^{\mathrm{ab}}$ & $15.4 \pm 1.0^{\mathrm{a}}$ & 0.012 & 0.263 \\
\hline
\end{tabular}

Faeces tested at $30 \mathrm{~d}$ of the experiment, $n=8$; Chyme colon data, $n=6$; Data are expressed as means \pm S.E.; $D F$, dietary fiber; Means with different letters ${ }^{\text {a,b }}$ denote $P<0.05$

Lactobacillus, Faecalibacterium, Prevotella_9, Alloprevotella, Prevotellaceae_UCG-003, Prevotella_7, Fibrobacter, Sphaerochaeta and Erysipelotrichaceae_UCG-004 are able to mobilise DF to produce SCFAs. Studies conducted on zebrafish revealed that the probiotic Lactobacillus rhamnosus exerted beneficial effects on oocyte development [30,31]. Additionally, Faecalibacterium was implicated to play a role in the pathogenesis of polycystic ovary syndrome (PCOS) in human [32-34]. On the other hand, 17 microbiota genera significantly decreased with increasing DF intake level, including Streptococcus and Escherichia-Shigella, which are pathogenic bacteria. A recent study revealed that an elevation in Bacteroides vulgatus was an important factor leading to PCOS in human [35]. Furthermore, studies conducted on humans revealed that the diversity of the gut microbiota is closely correlated with the morbidity of PCOS, in particular for those with obesity [34-36]. However, it remains unclear how the microbiota influences ovarian development in domestic animals such as pigs.

We conducted serum metabolomics analysis to explore the potential mechanism mediating the effects of DF on oocytes in gilts. The untargeted metabolomics analysis revealed significant changes in serum metabolites. Compared with gilts in the DF 1.0 group, the total number of metabolites that differed from those in DF 1.5, DF 1.75 and DF 2.0 groups was 92, 123 and 171 , respectively, indicating a dose-dependent regulation of DF intake level on serum metabolites. However, oocyte quality reached a peak in DF 1.75 gilts, implying an optimal DF intake level for replacement gilts, but the reason why a further increase in DF intake level resulted in no further improvement in reproductive traits compared with DF 1.75 gilts remains unclear and awaits further investigation.

We further explored the differential metabolites between DF 1.0 and DF 1.75 groups. Interestingly, KEGG pathway analysis revealed that some of those metabolites were gut-derived. For example, the serotonergic pathway derived from tryptophan metabolism in enterochromaffin cells of the gastrointestinal tract, in which tryptophan is converted to serotonin (also known as 5 -HT) by the enzyme tryptophan hydroxylase 1 encoded by the TPH1 gene [37]. It has been revealed that metabolites produced by the gut microbiota, such as SCFAs, bile acids, cholate, deoxycholate and p-aminobenzoate, can upregulate TPH1 gene expression and thereby stimulate serotonin secretion [38]. Over 95\% of serotonin is gutderived, and serotonin is believed to be a gut-derived

Table 8 Effects of dietary fiber intake level on serotonin concentration in serum, follicular fluid and colon tissues of gilts

\begin{tabular}{|c|c|c|c|c|c|c|}
\hline & \multicolumn{4}{|l|}{ Treatments } & \multicolumn{2}{|l|}{$P$-value } \\
\hline & $1.0 \mathrm{DF}$ & $1.5 \mathrm{DF}$ & $1.75 \mathrm{DF}$ & $2.0 \mathrm{DF}$ & Linear & $\overline{\text { Quadratic }}$ \\
\hline \multicolumn{7}{|c|}{ At $30 \mathrm{~d}$ of experiment } \\
\hline Serum, ng/mL & $1422.1 \pm 86.6^{\mathrm{b}}$ & $1713.4 \pm 1115.3^{\mathrm{ab}}$ & $2069.1 \pm 133.8^{\mathrm{a}}$ & $1879.5 \pm 105.5^{\mathrm{a}}$ & 0.001 & 0.226 \\
\hline $\mathrm{FF}, \mathrm{pg} / \mathrm{mL}$ & $209.8 \pm 16.0$ & $259.9 \pm 24.9$ & $286.1 \pm 16.8$ & $304.5 \pm 32.1$ & $<0.001$ & 0.356 \\
\hline \multicolumn{7}{|c|}{ At $19 \mathrm{~d}$ of the $2 \mathrm{rd}$ oestrous cycle } \\
\hline Serum, ng/mL & $646.8 \pm 42.4^{c}$ & $847.3 \pm 32.2^{b}$ & $1026.8 \pm 68.5^{\mathrm{ab}}$ & $1141.0 \pm 51.9^{a}$ & $<0.001$ & 0.598 \\
\hline $\mathrm{FF}, \mathrm{pg} / \mathrm{mL}$ & $112.7 \pm 10.0$ & $124.8 \pm 27.8$ & $179.6 \pm 35.8$ & $180.1 \pm 13.1$ & 0.032 & 0.724 \\
\hline Colons, ng/mg & $2.84 \pm 0.28^{b}$ & $3.05 \pm 0.24^{b}$ & $4.58 \pm 0.20^{\mathrm{a}}$ & $4.11 \pm 0.09^{\mathrm{a}}$ & $<0.001$ & 0.928 \\
\hline
\end{tabular}

Data are expressed as means \pm S.E.; means with different letters ${ }^{\text {a,b }}$ denote $P<0.05$. $D F$, dietary fiber; $F F$, follicular fluid; $n=6$ 
Table 9 Linear regression between butyric acid ( $x, \mu \mathrm{mol} / \mathrm{g})$ and serotonin in different tissues ${ }^{1}$

\begin{tabular}{lllll}
\hline Items & $\mathbf{b}_{\mathbf{0}}$ & $\mathbf{b}_{\mathbf{1}}$ & $\mathbf{R}^{\mathbf{2}}$ & $\boldsymbol{P}$-value \\
\hline Serotonin & & & & \\
$\quad$ Serum, $\mathrm{ng} / \mathrm{mL}$ & 24.705 & 67.739 & 0.624 & $<0.001$ \\
Follicular fluid, $\mathrm{pg} / \mathrm{mL}$ & -118.494 & 20.362 & 0.697 & $<0.001$ \\
Colon, $\mathrm{ng} / \mathrm{mg}$ & 1.266 & 0.181 & 0.281 & 0.008 \\
\hline
\end{tabular}

${ }^{1}$ The linear regression model is $y=b_{0}+b_{1} \times x$, where $b_{0}$ denotes serum serotonin concentrations when the butyrate concentration in colonic content was $0 \mu \mathrm{mol} / \mathrm{g}$, and $b_{1}$ denotes the serotonin increment when the colonic butyrate content was increased to $1 \mu \mathrm{mol} / \mathrm{g}$

metabolic signal $[38,39]$. In order to validate the effect of DF intake level on serotonin secretion, we measured the serum concentration of serotonin, and revealed a linear effect of DF intake on serum serotonin level. Consistently, the serotonin level in follicular fluid was also elevated by DF intake level. Serotonin receptors such as 5-hydroxytryptamine (HTR)1D, 5-HTR2 and 5-HTR7 are expressed in porcine ovarian tissues [13]. Injection of serotonin into crustaceans [40-42] and fish [43] resulted in improved ovarian follicular development and oocyte maturation. Serotonergic signalling in mammalian ovarian follicles and oocytes might play important roles in oocyte or early embryo survival [44]. Deletion of the rate-limiting enzyme-encoding gene $T p h 1$ resulted in elevated embryo death from $3.6 \%$ in wild-type to $80-89 \%$ in mice lacking Tph1 [45]. Therefore, serotonin might be one of the potential regulators mediating the effects of DF on oocyte maturation in gilts. Additionally, serotonin serves as the sole precursor of melatonin via the rate-limiting enzyme arylalkylamine- $\mathrm{N}$-acetyltransferase (AANAT), the expression of which can be up-regulated by the microbial metabolite butyrate in duodenal tissue and Caco-2 cells [46]. To clarify, we observed a dosedependent effect of DF on the concentration of melatonin in follicular fluids. Several lines of evidence have demonstrated that melatonin can promote the developmental competence of porcine oocytes [47-49]. Thus, the serotonin-melatonin pathway appears to be involved in the control of oocyte maturation following DF intake.

In addition, sphingolipid metabolism differed between gilts in DF 1.0 and DF 1.75 groups. Sphingolipids are lipids with a set of aliphatic amino alcohols that play an important role in cell recognition and signal transduction [50]. Ceramides are early products of sphingolipid synthetic pathways involved in the control of hepatic gluconeogenesis induced by the microbiota-bile acid pathway [51], and they impair porcine oocyte quality via regulation of mitochondrial oxidative stress and apoptosis $[52,53]$. Bile acids, steroid acids primarily produced by the liver, are secreted into the gut lumen upon feeding to assist the absorption of nutrients such as lipids and vitamins, glucose homeostasis, and regulation of energy expenditure
[54]. Liver-derived bile acids in mammals are usually considered primary acids, and most are re-absorbed via enterohepatic circulation. However, a small fraction of this pool (roughly 5\%) is able to escape reabsorption in the ileum and undergoes bacterial transformation in the colon, giving rise to secondary bile acids. In this study, the secondary bile acids deoxycholic acid and taurochenodeoxycholic acid were increased in DF 1.75 gilts compared with DF 1.0 gilts. Tauroursodeoxycholic acid was shown to facilitate DNA damage repair and improve early embryo development in pigs [55] and other mammals [56]. Additionally, DF intake also altered levels of other metabolites, including spermidine [57], 4-aminobenzoic acid [58] and ibuprofen [59] that are known to influence oocyte quality or reproductive function. However, we cannot exclude the possibility that these differentially abundant metabolites might act as primary signals to trigger secondary metabolic signals that influence oocyte and uterine development.

\section{Conclusion}

The current study provides evidence showing that increased DF intake exerts profound beneficial effects on oocyte maturation and uterine development in gilts. Notably, feeding replacement gilts additional intake of $419.5 \mathrm{~g} / \mathrm{d}$ DF in the form of inulin and cellulose at a 1:4 ratio on a corn-soybean meal based diet could optimize the oocyte and uterine development. We also observed that DF might increase the SCFA-producing microbe and gut-derived metabolites (such as serotonin) to exert the benefit on the oocyte quality and uterine development of replacement gilts, and thereby providing new microbial and metabolomic insight into the mechanisms mediating the effects of DF. The findings could help develop optimal nutritional strategies for replacement gilts, as well as dietary patterns for other mammals, including humans.

\section{Abbreviations}

DF: Dietary fiber; LY: Landrace $\times$ Yorkshire; SD: Standard deviation;

SCFAs: Short-chain fatty acids; CF: Crude fiber; NDF: Neutral detergent fiber; COC: Cumulus-oocyte complex; ELISA: Enzyme-linked immunosorbent assay; BMP15: Bone morphogenetic protein 15; GDF9: Growth differentiation factor 9; PCA: Principal component analysis; PCOS: Polycystic ovary syndrome; TPH1: Enzyme tryptophan hydroxylase 1; AANAT: Arylalkylamine-Nacetyltransferase

\section{Supplementary Information}

The online version contains supplementary material available at https://doi. org/10.1186/s40104-021-00657-0.

Additional file 1. Supplementary figures.

\section{Acknowledgements}

The authors wish to thank the laboratory staff for their ongoing assistance.

\section{Authors' contributions}

MC, DW and YZ designed and supervised the experiments. MC, YG, LH, LT,

$\mathrm{XJ}$ and $J \mathrm{~L}$ conducted the animal trial and performed data collection. ZM, LC, 
YL and ZF conducted statistical analyses. ZM and YZ analysed microbial 165 rRNA and metabolomics data. YZ and ZM wrote and revised the manuscript. All authors read and approved the final manuscript.

\section{Funding}

This study was supported by the Sichuan Science and Technology Program (2021YJ0287), and National Natural Science Foundation of China, PR China (31772616). The funding sources played no role in study design or the collection, analysis and interpretation of data, writing of the report, or in the decision to submit the paper for publication.

\section{Declarations}

\section{Competing interests}

The authors declare that they have no competing interests.

\section{Author details}

'Animal Nutrition Institute, Sichuan Agricultural University, 211 Huimin Road, Wenjiang District, Chengdu 611130, People's Republic of China. ${ }^{2}$ College of Animal Science and Technology, Sichuan Agricultural University, Chengdu 611130, People's Republic of China.

Received: 14 July 2021 Accepted: 25 November 2021

Published online: 13 January 2022

\section{References}

1. Williams BA, Mikkelsen D, Flanagan BM, Gidley MJ. "Dietary fibre": Moving beyond the "soluble/insoluble" classification for monogastric nutrition, with an emphasis on humans and pigs. J Anim Sci Biotechnol. 2019;10:45. https://doi.org/10.1186/s40104-019-0350-9.

2. Jha R, Fouhse JM, Tiwari UP, Li L, Willing BP. Dietary fiber and intestinal health of monogastric animals. Front Vet Sci. 2019;6:48. https://doi.org/10.33 89/fvets.2019.00048.

3. Jarrett $\mathrm{S}$, Ashworth CJ. The role of dietary fibre in pig production, with a particular emphasis on reproduction. J Anim Sci Biotechnol. 2018;9:59. https://doi.org/10.1186/s40104-018-0270-0.

4. Ferguson EM, Slevin J, Edwards SA, Hunter MG, Ashworth CJ. Effect of alterations in the quantity and composition of the pre-mating diet on embryo survival and foetal growth in the pig. Anim Reprod Sci. 2006;96(12):89-103. https://doi.org/10.1016/j.anireprosci.2005.11.007.

5. Ferguson EM, Slevin J, Hunter MG, Edwards SA, Ashworth CJ. Beneficial effects of a high fibre diet on oocyte maturity and embryo survival in gilts. Reproduction. 2007;133(2):433-9. https://doi.org/10.1530/REP-06-0018.

6. Weaver AC, Kelly JM, Kind KL, Gatford KL, Kennaway DJ, Herde PJ, et al. Oocyte maturation and embryo survival in nulliparous female pigs (gilts) is improved by feeding a lupin-based high-fibre diet. Reprod Fertil Dev. 2013; 25(8):1216-23. https://doi.org/10.1071/RD12329.

7. Cao M, Zhuo Y, Gong L, Tang L, Li Z, Li Y, et al. Optimal dietary fiber intake to retain a greater ovarian follicle reserve for gilts. Animals (Basel). 2019; 9(11):881. https://doi.org/10.3390/ani9110881.

8. Zhuo Y, Shi X, Lv G, Hua L, Zhou P, Che L, et al. Beneficial effects of dietary soluble fiber supplementation in replacement gilts: pubertal onset and subsequent performance. Anim Reprod Sci. 2017;186:11-20. https://doi. org/10.1016/j.anireprosci.2017.08.007.

9. Yang $M, M a o Z$, Jiang $X$, Cozannet $P, C h e ~ L, X u ~ S$, et al. Dietary fiber in a low-protein diet during gestation affects nitrogen excretion in primiparous gilts, with possible influences from the gut microbiota. J Anim Sci. 2021; 99(6):skab121. https://doi.org/10.1093/jas/skab121.

10. Zhuo Y, Feng B, Xuan Y, Che L, Fang Z, Lin Y, et al. Inclusion of purified dietary fiber during gestation improved the reproductive performance of sows. J Anim Sci Biotechnol. 2020;11:1. https://doi.org/10.1186/s40104-02000450-5.

11. Koh A, De Vadder F, Kovatcheva-Datchary P, Bäckhed F, Institute Of Medicine DOMA, Wallenberg L, et al. From dietary fiber to host physiology: Short-Chain fatty acids as key bacterial metabolites. Cell. 2016;165(6):133245. https://doi.org/10.1016/j.cell.2016.05.041.

12. Frampton J, Murphy KG, Frost G, Chambers ES. Short-chain fatty acids as potential regulators of skeletal muscle metabolism and function. Nat Metab. 2020;2(9):840-8. https://doi.org/10.1038/\$42255-020-0188-7.

13. Zhuo $Y$, Cao M, Gong $Y$, Tang $L$, Jiang $X$, Li Y, et al. Gut microbial metabolism of dietary fibre protects against high energy feeding induced ovarian follicular atresia in a pig model. Br J Nutr. 2021;125(1):38-49. https:// doi.org/10.1017/S0007114520002378.

14. Englyst HN, Cummings JH. Improved method for measurement of dietary fiber as non-starch polysaccharides in plant foods. J Assoc Off Anal Chem. 1988;71(4):808-14

15. Van Soest PJWR. Determination of lignin and cellulose in acid-detergent fiber with permanganate. J Association Off Anal Chem. 1968;4(51):780-5. https://doi.org/10.1093/jaoac/51.4.780.

16. Mudgil D, Barak S. Composition, properties and health benefits of indigestible carbohydrate polymers as dietary fiber: a review. Int J Biol Macromol. 2013;61:1-6. https://doi.org/10.1016/j.jijbiomac.2013.06.044.

17. Gill SK, Rossi M, Bajka B, Whelan K. Dietary fibre in gastrointestinal health and disease. Nat Rev Gastroenterol Hepatol. 2021;18(2):101-16. https:/doi. org/10.1038/s41575-020-00375-4.

18. Zhou DS, Fang ZF, Wu D, Zhuo Y, Xu SY, Wang YZ, et al. Dietary energy source and feeding levels during the rearing period affect ovarian follicular development and oocyte maturation in gilts. Theriogenology. 2010;74(2): 202-11. https://doi.org/10.1016/j.theriogenology.2010.02.002.

19. Wu D, Cheung QC, Wen L, Li J. A growth-maturation system that enhances the meiotic and developmental competence of porcine oocytes isolated from small follicles1. Biol Reprod. 2006;75(4):547-54. https://doi.org/10.1095/ biolreprod.106.051300.

20. Jha R, Berrocoso JD. Review: dietary fiber utilization and its effects on physiological functions and gut health of swine. Animal. 2015;9(9):1441-52. https://doi.org/10.1017/S1751731115000919.

21. Krisher RL. The effect of oocyte quality on development. J Anim Sci. 2004; 82(E-Suppl):E14-23. https://doi.org/10.2527/2004.8213_supplE14x.

22. Da SC, Broekhuijse M, Laurenssen B, Mulder HA, Knol EF, Kemp B, et al. Relationship between ovulation rate and embryonic characteristics in gilts at 35 d of pregnancy. J Anim Sci. 2017;95(7):3160-72. https://doi.org/10.252 7/jas.2017.1577.

23. Patterson J, Foxcroft G. Gilt management for fertility and longevity. Animals (Basel). 2019;9:7. https://doi.org/10.3390/ani9070434.

24. Hart RJ. Physiological aspects of female fertility: role of the environment, modern lifestyle, and genetics. Physiol Rev. 2016;96(3):873-909. https://doi. org/10.1152/physrev.00023.2015.

25. Nelson SM. Biomarkers of ovarian response: current and future applications. Fertil Steril. 2013;99(4):963-9. https://doi.org/10.1016/j.fertnstert.2012.11.051.

26. Zhang H, Liu K. Cellular and molecular regulation of the activation of mammalian primordial follicles: somatic cells initiate follicle activation in adulthood. Hum Reprod Update. 2015;21(6):779-86. https://doi.org/10.1093/ humupd/dmv037.

27. Calderon DJ, Vallet JL, Lents CA, Nonneman DJ, Miles JR, Wright EC, et al. Age at puberty, ovulation rate, and uterine length of developing gilts fed two lysine and three metabolizable energy concentrations from 100 to 260 d of age. J Anim Sci. 2015;93(7):3521-7. https://doi.org/10.2527/jas.20148522.

28. Vallet JL, McNeel AK, Johnson G, Bazer FW. Triennial reproduction symposium: limitations in uterine and conceptus physiology that lead to fetal losses. J Anim Sci. 2013;91(7):3030-40. https://doi.org/10.2527/jas.20126138

29. Makki K, Deehan EC, Walter J, Backhed F. The impact of dietary fiber on gut microbiota in host health and disease. Cell Host Microbe. 2018;23(6):705-15. https://doi.org/10.1016/j.chom.2018.05.012.

30. Hu C, Liu M, Tang L, Sun B, Huang Z, Chen L. Probiotic Lactobacillus rhamnosus modulates the impacts of perfluorobutanesulfonate on oocyte developmental rhythm of zebrafish. Sci Total Environ. 2021;776:145975. https://doi.org/10.1016/j.scitotenv.2021.145975.

31. Giorgini E, Conti C, Ferraris P, Sabbatini S, Tosi G, Rubini C, et al. Effects of Lactobacillus rhamnosus on zebrafish oocyte maturation: an FTIR imaging and biochemical analysis. Anal Bioanal Chem. 2010;398(7-8):3063-72. https://doi.org/10.1007/s00216-010-4234-2.

32. Zhang J, Sun Z, Jiang S, Bai X, Ma C, Peng Q, et al. Probiotic bifidobacterium lactis $\mathrm{v} 9$ regulates the secretion of sex hormones in polycystic ovary syndrome patients through the Gut-Brain axis. mSystems. 2019;4:2. https:// doi.org/10.1128/mSystems.00017-19.

33. Chu W, Han Q, Xu J, Wang J, Sun Y, Li W, et al. Metagenomic analysis identified microbiome alterations and pathological association between intestinal microbiota and polycystic ovary syndrome. Fertil Steril. 2020; 113(6):1286-98. https://doi.org/10.1016/j.fertnstert.2020.01.027. 
34. Guo J, Shao J, Yang Y, Niu X, Liao J, Zhao Q, et al. Gut microbiota in patients with polycystic ovary syndrome: a systematic review. Reprod Sci. 2021. https://doi.org/10.1007/s43032-020-00430-0.

35. Qi X, Yun C, Sun L, Xia J, Wu Q, Wang Y, et al. Gut microbiota-bile acidinterleukin-22 axis orchestrates polycystic ovary syndrome. Nat Med. 2019; 25(9):1459. https://doi.org/10.1038/s41591-019-0562-8.

36. Jobira B, Frank DN, Pyle L, Silveira L, Kelsey MM, Garcia-Reyes Y, et al. Obese adolescents with PCOS have altered biodiversity and relative abundance in gastrointestinal microbiota. J Clin Endocrinol Metab. 2020; 105(6):e2134-44. https://doi.org/10.1210/clinem/dgz263.

37. Shajib MS, Baranov A, Khan WI. Diverse effects of gut-derived serotonin in intestinal inflammation. ACS Chem Neurosci. 2017;8(5):920-31. https://doi. org/10.1021/acschemneuro.6b00414.

38. Yano JM, Yu K, Donaldson GP, Shastri GG, Ann P, Ma L, et al. Indigenous Bacteria from the gut microbiota regulate host serotonin biosynthesis. Cell. 2015;161(2):264-76. https://doi.org/10.1016/j.cell.2015.02.047.

39. Sun E, Martin AM, Young RL, Keating DJ. The regulation of peripheral metabolism by Gut-Derived hormones. Front Endocrinol (Lausanne). 2018;9: 754. https://doi.org/10.3389/fendo.2018.00754.

40. Meeratana $P$, Withyachumnarnkul B, Damrongphol P, Wongprasert $K$, Suseangtham A, Sobhon P. Serotonin induces ovarian maturation in giant freshwater prawn broodstock, Macrobrachium rosenbergii de man. Aquaculture. 2006;260(1-4):315-25. https://doi.org/10.1016/j.aquaculture.2006.06.010

41. Wongprasert K, Asuvapongpatana S, Poltana P, Tiensuwan M, Withyachumnarnkul B. Serotonin stimulates ovarian maturation and spawning in the black tiger shrimp Penaeus monodon. Aquaculture. 2006; 261(4):1447-54. https://doi.org/10.1016/j.aquaculture.2006.08.044.

42. Tomy S, Saikrithi P, James N, Balasubramanian CP, Panigrahi A, Otta SK, et al. Serotonin induced changes in the expression of ovarian gene network in the Indian white shrimp. Aquaculture. 2016;452:239-46. https://doi.org/10.1 016/j.aquaculture.2015.11.003

43. Prasad $\mathrm{P}$, Ogawa $\mathrm{S}$, Parhar IS. Role of serotonin in fish reproduction. Front Neurosci. 2015;9:195. https://doi.org/10.3389/fnins.2015.00195.

44. Dube F, Amireault P. Local serotonergic signaling in mammalian follicles, oocytes and early embryos. Life Sci. 2007;81(25-26):1627-37. https://doi. org/10.1016/j.lfs.2007.09.034.

45. Cote F, Fligny C, Bayard E, Launay JM, Gershon MD, Mallet J, et al. Maternal serotonin is crucial for murine embryonic development. Proc Natl Acad Sci U S A. 2007;104(1):329-34. https://doi.org/10.1073/pnas.0606722104.

46. Jin CJ, Engstler AJ, Sellmann C, Ziegenhardt D, Landmann M, Kanuri G, et al Sodium butyrate protects mice from the development of the early signs of non-alcoholic fatty liver disease: role of melatonin and lipid peroxidation. $\mathrm{Br}$ J Nutr. 2016;1 16(10):1682-93. https://doi.org/10.1017/S0007114516004025.

47. Jin JX, Lee S, Taweechaipaisankul A, Kim GA, Lee BC. Melatonin regulates lipid metabolism in porcine oocytes. J Pineal Res. 2017;62(2):2. https://doi. org/10.1111/jpi.12388.

48. Miao Y, Zhou C, Bai Q, Cui Z, ShiYang X, Lu Y, et al. The protective role of melatonin in porcine oocyte meiotic failure caused by the exposure to benzo(a)pyrene. Hum Reprod. 2018;33(1):116-27. https://doi.org/10.1093/ humrep/dex331.

49. Cao Z, Gao D, Tong X, Xu T, Zhang D, Wang Y, et al. Melatonin improves developmental competence of oocyte-granulosa cell complexes from porcine preantral follicles. Theriogenology. 2019;133:149-58. https://doi. org/10.1016/j.theriogenology.2019.05.003.

50. Maceyka M, Spiegel S. Sphingolipid metabolites in inflammatory disease. Nature. 2014;510(7503):58-67. https://doi.org/10.1038/nature13475.

51. Xie C, Jiang C, Shi J, Gao X, Sun D, Sun L, et al. An intestinal farnesoid X receptor-ceramide signaling axis modulates hepatic gluconeogenesis in mice. Diabetes. 2017;66(3):613-26. https://doi.org/10.2337/db16-0663.

52. Park KM, Wang JW, Yoo YM, Choi MJ, Hwang KC, Jeung EB, et al. Sphingosine-1-phosphate (S1P) analog phytosphingosine-1-phosphate (P1P) improves the in vitro maturation efficiency of porcine oocytes via regulation of oxidative stress and apoptosis. Mol Reprod Dev. 2019;86(11):1705-19. https://doi.org/10.1002/mrd.23264.

53. Itami N, Shirasuna K, Kuwayama T, Iwata H. Palmitic acid induces ceramide accumulation, mitochondrial protein hyperacetylation, and mitochondrial dysfunction in porcine oocytes. Biol Reprod. 2018;98(5):644-53. https://doi. org/10.1093/biolre/ioy023.

54. Ahmad TR, Haeusler RA. Bile acids in glucose metabolism and insulin signalling - mechanisms and research needs. Nat Rev Endocrinol. 2019; 15(12):701-12. https://doi.org/10.1038/s41574-019-0266-7.
55. Dicks N, Gutierrez K, Currin L, Priotto DMM, Glanzner W, Michalak M, et al. Tauroursodeoxycholic acid acts via TGR5 receptor to facilitate DNA damage repair and improve early porcine embryo development. Mol Reprod Dev. 2020;87(1):161-73. https://doi.org/10.1002/mrd.23305.

56. Deng T, Xie J, Ge H, Liu Q, Song X, Hu L, et al. Tauroursodeoxycholic acid (TUDCA) enhanced intracytoplasmic sperm injection (ICSI) embryo developmental competence by ameliorating endoplasmic reticulum (ER) stress and inhibiting apoptosis. J Assist Reprod Genet. 2020;37(1):119-26. https://doi.org/10.1007/s10815-019-01627-2.

57. Jin JX, Lee S, Khoirinaya C, Oh A, Kim GA, Lee BC. Supplementation with spermine during in vitro maturation of porcine oocytes improves early embryonic development after parthenogenetic activation and somatic cell nuclear transfer. J Anim Sci. 2016;94(3):963-70. https://doi.org/10.2527/jas.2 015-9761.

58. Chang CC, Hsieh YY, Chung JG, Tsai HD, Tsai CH. Kinetics of acetyl coenzyme a: Arylamine N-acetyltransferase from human cumulus cells. J Assist Reprod Genet. 2001;18(9):512-8. https://doi.org/10.1023/a:101 6605211332.

59. Kohl SA, Burkard S, Mitter VR, Leichtle AB, Fink A, Von Wolff M. Short-term application of ibuprofen before ovulation. Facts Views Vis Obgyn. 2020; 12(3):179-84.
Ready to submit your research? Choose BMC and benefit from:

- fast, convenient online submission

- thorough peer review by experienced researchers in your field

- rapid publication on acceptance

- support for research data, including large and complex data types

- gold Open Access which fosters wider collaboration and increased citations

- maximum visibility for your research: over $100 \mathrm{M}$ website views per year

At BMC, research is always in progress.

Learn more biomedcentral.com/submissions 